\title{
Pluralism or Fragmentation?: The Twentieth-Century Employment Law Regime in Canada
}

Judy Fudge

Osgoode Hall Law School of York University

Eric Tucker

Osgoode Hall Law School of York University, etucker@osgoode.yorku.ca

Source Publication:

Labour/Le Travail. Volume 46 (2000), p. 251-306.

Follow this and additional works at: https://digitalcommons.osgoode.yorku.ca/scholarly_works (c) (1) $(9)$

This work is licensed under a Creative Commons Attribution-Noncommercial-No Derivative Works 4.0 License.

\section{Recommended Citation}

Fudge, Judy, and Eric Tucker. "Pluralism or Fragmentation? The Twentieth-Century Employment Law Regime in Canada." Labour/Le Travail 46 (2000): 251-306.

This Article is brought to you for free and open access by the Faculty Scholarship at Osgoode Digital Commons. It has been accepted for inclusion in Articles \& Book Chapters by an authorized administrator of Osgoode Digital Commons. 


\section{LAW, INDUSTRIAL RELATIONS, AND THE STATE}

\section{Pluralism or Fragmentation?: The Twentieth-Century Employment Law Regime in Canada}

Judy Fudge and Eric Tucker

\section{Introduction: Employment Regimes and Fragmented Labour Markets}

ANY ATTEMPT AT A HISTORICAL overview inevitably involves contentious choices, including those of focus, the analytic lens to deploy, and the themes that structure the narrative. The first and most controversial choice that we have made is that of focus. Our topic is the legal regulation of employment in 20th-century Canada. Despite the fact that during the 20th century employment has come to be treated as a synonym for work, these terms are not equivalent. Employment is a mere subset of the broader domain of work; it emerged as a specific legal category in England in the 19th century to specify the rights and obligations that comprised a bilateral labour market contract. Work, by contrast, captures a much broader range of productive activity, including the labour of small independent producers and women in the houschold. The false equivalence of the terms "employment" and "work" in the 20th century is evidence of the hegemony of the neo-classical vision of the labour market in which employment dominates.

${ }^{\prime}$ R.E. Pahl, On Work: Historical, Comparative and Theoretical Approaches (Oxford 1988). Also sec Ann Forrest, "The Industrial Relations Significance of Unpaid Work," Labour/ Le Travail, 42 (1998), 199-225; Belinda Leach, "Industrial Homework, Economic Restructur-

Judy Fudge and Eric Tucker, "Pluralism or Fragmentation?: The Twenticth Century Employment Law Rcgime in Canada," Labour/Le Travail, 46 (Fall 2000), 251-306. 
Our focus on employment reflects the separation of home and waged work that characterized the new industrial age. By the turn of the twentieth century, the once dominant form of family production was becoming a faint memory in most parts of Canada, replaced by a new sexual division of labour characterized by male employment and female domestic labour - an arrangement that deepened and expanded women's dependence on men's wages. One negative consequence of our focus on employment, then, is that it privileges the work experience of men over that of women. ${ }^{2}$

We also are aware that an exclusive focus on employment is becoming less defensible at the end of the 20th century as owners of capital seek ways of getting work done that does not entail entering into employment relations. Indeed, the coherence of the legal categories of employer and employee is being undermined by this inventiveness. We certainly doubt that it will be defensible for a history of the legal regulation of work in the 21 st century to focus on the sub-category of employment.

Yet, despite its ideological baggage, gender-blindness, and partiality, a review of the 20th century focused on the legal regulation of employment is sensible both because employment has been the principal means through which productive relations were established and governed and because employment relations have been the primary subject of the legal regulation of work through most of this century. Other ways of organizing work have been subject to far less legal control, so that what is really notable in this regard are law's silences and exclusions, not its words and actions. Employment relations became a magnet for legal regulation precisely because it was through these relations that most families obtained access to the means necessary for their survival and reproduction and because, from time to time, their conflictual character threatened to disrupt the social order.

Our analytical lens is that of a regime of legal regulation by which we mean the constellation of laws, institutions, and ideologies through which employment relations are organized and legitimated. This heuristic allows us to capture both the continuities and dynamics of legal regulation as it developed over the 20th century. Central to the regime is the contract of employment within which the judiciary inscribed the legal subordination of the worker by implying duties of obedience and loyalty derived from older notions of status at the same time that it endorsed

ing and the Meaning of Work," Labour/ Le Travail, 41 (Spring), 97-115; Christopher Tomlins, "Why Wait for Industrialism? Work, Legal Culture, and the Example of Early America - An Historical Argument," Labor History, 40 (1999), 5-33; and Chris Tilly and Charles Tilly, Work Under Capitalisth (Westview 1999).

${ }^{2}$ Pat Armstrong and Hugh Armstrong, The Double Ghetto: Canadian Women \& Their Segregated Work, 3rd ed. (Toronto 1994), 83; Tannis Peikoff and Stephen Brickey, "Creating Precious Children and Glorified Mothers: A Theoretical Assessment of the Transformation of Childhood," in Elizabeth Comack and Stephen Brickey, eds., The Social Basis of Law, 2nd ed. (Halifax 1991), 71-94; Wally Seccombe, "The Housewife and her Labour under Capitalism," New Lef Review, 83 (1973), 3-24, 6. 
free exchange and exclusive private property rights. This juridical construction, however, could not resolve the inevitable conflicts over the employment relation and its governance fuelled by conflicting material interests and competing visions of justice. ${ }^{3}$

Three conceptions of justice have been invoked to deal with these conflicts. One relies upon market competition for labour to limit the abuses of property rights. Voluntary individual contracts, enforced by the courts, guarantee workers market freedom. In another conception of justice, workers' collective action to assert and enforce employment rights provides the crucial mechanism for the achievement of justice by offsetting the employers' superior bargaining power. Democratic freedoms, especially those of expression and association, provided the legitimacy for workers' collective institutions and actions. The third conception is rooted in democratic politics and involves direct state regulation of the terms of employment in accordance with politically determined norms of social and economic justice. ${ }^{4}$

These conceptions of justice were institutionalized in the employment law regime, albeit by no means in equal measure. By 1900 , the regime consisted roughly of three parts: the common law contract of employment, the law of collective action, and statutory minimum standards. While it is tempting to associate each conception of justice with a component of the legal regime, reality defies such neat categorizations. Class struggle and ideological conflict were endemic throughout the entire regime and in each of its components, although the level of contestation ebbed and flowed and its location varied.

The third crucial choice we made is to emphasize the theme of fragmentation, and in particular, the role of law in supporting, constituting and challenging fragmented labour markets. This theme was selected because it allows us explicitly to take issue with industrial pluralism, the predominant approach to post-war Canadian employment relations. ${ }^{5}$ According to it, after World War II, collective bargaining legislation administered by independent labour boards combined with a system of grievance arbitration to enforce collective agreements, to create a

${ }^{3}$ Daniel Jacoby, Laboring for Freedom: A New Look at the History of Labor in America (Armonk, NY 1998); Harry Glasbeek, "The Contract of Employment at Common Law," in John Anderson and Morley Gunderson, eds., Union-Management Relations (Toronto 1982), 47-77; Alan Fox, Beyond Contract: Work, Power and Trust (London 1974), 185; Margaret McCallum, "Labour and the Liberal State: Regulating the Employment Relationship, 1867-1920," Manitoba Law Journal, 23 (1995), 574-93.

4 Jacoby, Laboring for Freedom, 8.

${ }^{5}$ Bora Laskin, first as a labour law professor and arbitrator and then as an Ontario Court of Appeal and Supreme Court of Canada judge, was one of the earliest and most prominent proponents of this view. See W. Laird Hunter, "Bora Laskin and Labour Law: The Formative Years," Supreme Court Law Review, 6 (1984), 43!-66. More generally, sce H.W. Arthurs, "Developing Industrial Citizenship: A Challenge for Canada's Second Century," Canadian Bar Review, 45 (1967), 786-830; Task Force on Labour Relations, Canadian Industrial Relations: Final Report (Ottawa 1968). 
fundamentally different regime in which workers enjoyed the benefits of industrial citizenship. By contrast, we argue that collective bargaining expanded selectively and that most workers relied on individual contracts and minimum standards for the determination of their working conditions. Moreover, it was not simply the case that there was a plurality of institutions for the determination of conditions, but that the contours of labour market fragmentation significantly affected workers' access to the regime's various components.

Canada's highly tegionalized political economy is one important source of fragmentation. Another is its complicated and decentralized political geography that divides state power between national, provincial, and local authorities. A third dimension of fragmentation is captured by labour market segmentation theory, which identifies primary and secondary labour markets and emphasizes ascribed characteristics such as gender and race, and institutional factors, such as state policies and union structures and practices, as determinants of where workers are likely to be located. Workers in primary labour markets are employed by large employers, partially shielded from competition, where collective bargaining has taken hold to produce conditions of employment that are comparatively good, while those in secondary markets are employed in more marginal and competitive sectors of the economy, where unionization rates are low, jobs lack security, and pay is poor, ${ }^{6}$

Although fragmented labour markets sometimes appear to be "natural" categories arising from "objective" differences, they are socially constructed. While these processes are complex, involving both structure and agency, we hope to show the salience of law as an instrument and an ideology through which fragmentation is institutionalized, reinforced, and contested by the actions of employers and workers. We hope also to demonstrate that an examination of the history of employment law as an instrument of fragmentation captures some of its most important features and dynamics in 20th-century Canada and illuminates the relations between its different components.

To capture the continuities and dynamics of the legal regime, we have divided the century into two periods that allow us to amplify and capture some of the most significant changes in the patterns of legal regime institutionalization. We have labelled the period from 1900 to 1948 as "industrial voluntarism" in order to capture its central characteristic: the overwhelming predominance of legal norms associated with market regulation, subject to a marginal role for state intervention through limited compulsory conciliation and direct regulation only for the most vulnerable. We have adopted the more conventional term "industrial pluralism" to identify the

${ }^{6}$ Peter B. Doeringer and Michael J. Piore, Internal Labor Markets and Manpower Analysis, 2nd ed. (Lexington 1985); David Gordon, Richard Edwards, and Michael Reich, Segmented Work, Divided Workers: The Historical Transformation of Workers in the United States (Cambridge 1982); Barbara L. Marshall, Engendering Modernity: Feminism, Social Theory and Social Change (Cambridge 1994). 
second period, from 1948 to 2000 to recognize that the era following World War II signals the legal institutionalization of workers' collective institutions and the simultaneous growth of direct state regulation of the terms of the employment contract as a subordinate mechanism to collective bargaining. It also marks the development of an industrial jurisprudence and a conception of industrial democracy to replace the hegemony of contract law as the organizing principle of employment.

\section{Industrial Voltuntarism, 1900-48}

\section{Constructing the Regime of Industrial Voluntarism, 1900-1914}

At the turn of the century, the transition from competitive to monopoly capitalism profoundly altered class relations. The National Policy promoted the expansion of manufacturing capacity and resource exploitation, both of which depended upon an infusion of foreign capital and immigrant workers. The benefits of this unprecedented economic growth, however, were not enjoyed equally. Between 1900 and the outbreak of World War I, productivity and prices soared, but wages lagged behind as working people struggled unsuccessfully to keep up with inflation.

They were hampered in their efforts by increasing class fragmentation. The sexual division of labour both between and within the household and workplace was deeply entrenched, even as women's employment increased. In general, women's wages were roughly 40 to 60 per cent of men's. Ethnic and racial fragmentation grew in significance as different immigrant groups were recruited by employers to perform specific types of labour. The skilted crafts were composed almost exclusively of workers of Anglo-Saxon descent who, through their unions, pursued policies of ethnic and racial exclusion and advocated immigration restrictions. Craft unions exercised some control over the labour process in the early years of the century and extracted a share of the benefits of economic prosperity. Unskilled workers who made up the majority of the country's labour force, however, were not strategically placed in the production process and lacked the organizational resources to win improved wages and conditions. ${ }^{8}$

${ }^{7}$ Bryan D. Palmer, Working-Class Experience, 2nd ed., (Toronto 1992), ch. 4; Paul Craven, "An Impartial Unpire": Industrial Relations and the Canadian Siate, 1900-19I/ (Toronto 1980), ch. 4; Donald Avery, Reluctant Host. Canada's Response to Immigrant Workers. 1869-1994 (Toronto 1995), ch. 1; Terry Copp, The Anatomy of Poverty: The Condition of the Working Class in Montreal, 1879 - 1929 (Toronto 1974), ch. 2; Michael J. Piva, The Condition of the Working Class in Toronto - 1900-1921 (Ottawa 1979), ch.2; Mary MacKinnon, "New Evidence on Canadian Wage Rates, 1900-1930," Canadian Journal of Economics, 39 (1996), I15-31.

${ }^{8}$ Wayne Roberts, Honest Womanhood: Feminism, Femininity and Class Consciousness among Toronto Working Women, 1893-19/4 (Toronto 1976); Marie Campbell, "Scxism in British Columbia Trade Unions, 1900-1920," in Barbara Latham and Cathy Kess, eds., In Her Own Right: Selected Essays on Women's History in BC (Victoria 1980), 167-186; 
The turn of the century was marked by a major strike wave in Canada, much of it led by skilled workers resisting their employers' efforts to carry through a second industrial revolution. But industrial action was not confined to this relatively privileged segment of the workforce; semi-and unskilled workers in the resource industries and on the public infrastructure frequently confronted their employers en masse to protest against their poor wages, dangerous working conditions and unsanitary habitation. Mass industrial unrest also erupted in Canadian cities, which grew at an astonishing rate during the first decade and a half of the century.

There were two prongs to the state's response to this strike wave. First, there was a refinement of the instruments of coercion. Some of this was accomplished in the courts where the judiciary held trade unionists civilly liable to employers for damages caused by various strike activities. Picketing was narrowly limited to protect employer property rights and the right of employers and non-striking workers to contract freely. This development in civil law was closely associated with the judicial interpretation of the criminal law of watching and besetting. Most judges were not prepared to hold that peaceful picketing per se was criminal, however, acts such as calling non-striking workers "scabs" attracted criminal sanction. Employers also used the law to limit broader manifestations of workingclass solidarity. Secondary action such as organized consumer boycotts and refusals by workers to handle struck work were held to be civil conspiracies to injure.

Adequate remedies were needed to make these civil actions effective. Procedural rules expedited employer applications for injunctions that prohibited the unlawful conduct under threat of punishment. There was also much litigation over whether a union as an entity could be made financially responsible for the wrongful acts of its members. The situation was not always entirely clear, but the general view was that while a union could not be sued directly in its own name, its funds could be reached through a representative action against the union's officers. ${ }^{9}$

In sum, the courts further institutionalized a market-based conception of justice, which constructed workers and employers as juridically equal, rightsbearing subjects. The selection of rights, however, was far from neutral. Priority was given to rights of property and contract, rights that were quintessentially negative, aiming to protect the individual against interference. Their protection entailed the imposition of limitations on the positive freedom of workers to engage in collective action to advance their interests. Workers recognized the class bias of

Mercedes Stecdman, Angels of the Workplace: Women and the Construction of Gender Relations in the Canadian Clothing Industry. 1890 -1940 (Toronto 1993); Linda Kealey, Enlisting Women for the Cause: Women, Labour and the Left in Canada, $1890-1920$ (Toronto 1998).

${ }^{9}$ Eric Tucker and Judy Fudge, "Forging Responsible Unions: Metal Workers and the Rise of the Labour Injunction in Canada," Labour/Le Travail, 37 (Spring 1996), 81-120. 
the courts but were unable to mobilize enough political support for legislation overriding these decisions, except in British Columbia. ${ }^{10}$

Although these legal principles applied to all labour market actors, craft workers were most subjected to them. Not only were their tactics more amenable to legal controls, but because these workers established permanent organizations, legal actions that threatened their assets could be particularly effective. While other workers did not experience directly the sting of judge-made law, it still affected them. Judicial pronouncements on the realm of permissible trade-union activity were important not only for their immediate legal consequences; they also aided in constructing a normative framework that legitimated other state actions, at least in the eyes of those who were inclined to believe law's words. The -legal characterization of behaviour as wrongful or criminal provided a justification for government officials to deploy police or militia to restore the judicially endorsed view of public order. ${ }^{11}$

The deployment of direct state coercion was highly uneven in the pre-war period. Most craft unions could operate more or less successfully within the confines of the law and avoid confrontation with police authority. The situation of semi-skilled industrial workers was more difficult. They often confronted employers determined to resist unionization and frequently lacked the organizational strength to overcome that resistance. Faced with the threat of replacements, these workers resorted to more muscular tactics. In smaller communities, local police sometimes lacked the capacity or the will to defend employers' rights of property and contract to the extent employers demanded. In some regions, powerful employers could rely on economically dependent provincial governments for coercive assistance. Moreover, since many of the industrial unions espoused radical ideas and welcomed immigrant workers into their ranks, this made them dangerous in the eyes of employers and state officials, justifying close surveillance and, ultimately, direct coercion, including the deployment of the militia, police raids, prosecutions, and deportations. Dangerous foreigners and subversives, unlike respectful working men, could not count upon the strain of mercy in British justice. $^{12}$

The second prong of the state's response aimed to promote conciliation and accommodation between employers and responsible unions as a strategy for ${ }^{10} \mathrm{For}$ a fruitful application of the distinction between positive and negative frecdoms in the labour context, sec Jacoby, Laboring for Freedom. On the BC legislation, sec A.W.R. Carrothers, "A Legislative History of the B.C. Trade-Unions Act: The Rossland Miners' Case," U.B.C. Legal Notes, 2 (1956), 339-46.

${ }^{11}$ Douglas Hay, "Time, Inequality, and Law's Violence," in Austin Sarat and Thomas R. Kearns, eds., Law's Violence (Ann Arbor 1992), 14!-73.

${ }^{12}$ Greg Marquis, "Doing Justice to 'British Justice': Law, Ideology and Canadian Historiography," in W. Wesley Pue and Barry Wright, eds., Canadian Perspectives on Law and Society: Issues in Law and History (Ottawa 1988), 43-69; Mark Leier, Where the Fraser River Flows: The Industrial Workers of the World in British Columbia (Vancouver 1990). 
reducing industrial conflict. To qualify for this treatment, unions had to demonstrate their support for the judicially constructed regime of industrial legality by not violating rights of property and contract or engaging in secondary actions such as sympathetic strikes or boycotts. To this end, the federal government began developing a legislative framework and an institutional infrastructure that enabled state officials to facilitate the settlement of disputes with a minimum of distuption. Industrial conflict that interfered with the success of its National Policy was particularly troubling and so the federal government's efforts focused on public utilities, defined to include mines, transportation, communications, and gas, electric, and power works. It claimed constitutional authority to legislate in these areas on the basis of its residual "peace, order and good government" powers. ${ }^{13}$

In 1900, the Laurier government established a Department of Labour which published the Labour Gazette (the official organ of labour relations information), and administered the newly enacted Conciliation Act. Mackenzie King was the department's chief bureaucrat and he shaped the government's labour policy over the coming years. The Conciliation ACt (1900) provided the first general legal framework for federal intervention in labour disputes. It authorized the Minister to investigate a dispute and arrange a conference between the parties. As well, either party could request conciliation, however, there was no legal obligation to participate. The scheme's implementation tended to reflect King's personal predilections. His primary concern was to restore production on the basis of market conditions, rather than to advance some other idea of economic justice. Thus, the government's policies rested firmly within the realm of " voluntarism."

Federal conciliation proved to be ineffective in resolving railway and mining strikes where recognition issues often loomed large. But even the potentially serious consequences of railway strikes to the national economy could not persuade the federal government to compel recognition or impose compulsory arbitration. Instead, the Railway Labour Disputes Act (1903) provided that conciliation could be followed by non-binding arbitration by an ad hoc tripartite board authorized to conduct a quasi-judicial investigation (including the power to compel testimony and order the production of documents) and to issue a normative report recommending terms of settlement.

Although little used, this legislation was an important precedent when Mackenzie King decided, after a series of particularly bitter and hard-fought strikes involving intervention by the militia, that stronger legislation was required to contain industrial conflict. The 1907 Industrial Dispute Invesigation ACt (IDIA) not only incorporated the use of tripartite conciliation boards, but prohibited resort to industrial action prior to the completion of the board's work. Persons who

${ }^{13}$ Craven, "An Impartial Umpire"; Bob Russell, Back to Work? Labour, State and Industrial Relations In Canada (Scarborough 1990), ch. 3; Jeremy Webber, "Compelling Compromise: Canada Chooses Conciliation over Arbitration, 1900-1907," Labour/Le Travail, 28 (1991), 15-54. 
violated the prohibition were liable to be prosecuted under the Criminal Code, although they rarely were. Conciliation was compulsory with respect to public utilities, but could be invoked by the mutual agreement of any disputants. It was hoped that delay and investigation would encourage the parties to accept the boards' recommendations which would be supported by enlightened public opinion. Government imposition of terms and conditions was still not accepted as a legitimate altenative to market voluntarism. ${ }^{14}$

The instrumental impact of the IDIA on those workers covered by its mandatory provisions was equivocal prior to World War I. Workers were most successful when they could force negotiations without state intervention; resort to IDIA conciliation was a second-best strategy. But it was also intended that the IDIA would have an ideological impact through the production by conciliation boards of a template of legitimate demands and acceptable conduct, publicized through the Labour Gazette. Boards generally accepted that workers should be entitled to a living wage, subject to the employer's ability to pay, and to be free to join a trade union without suffering discrimination, while employers should be free to manage their enterprises and maintain an open shop. On the issue of recognition, conciliation boards generally supported negotiation with employee committees when employers refused to deal with trade union representatives. This normative framework did not, however, gain widespread acceptance either among unions or employers. At best, there was pragmatic acceptance depending on the balance of power, but the practice of conciliation did not alter that balance. ${ }^{15}$

The simultaneous expansion of the state's power to coerce and to conciliate produced a regime of industrial legality that was both more powerful and more flexible than before. While the incremental increase in coercive power was more significant than the increase in conciliation, this dual development enabled the government more finely to calibrate the regime so that it could support the development of responsible trade unionism (understood to refer to unions that agreed to operate within the narrow confines of a market-based model of industrial legality) and impede more radical manifestations of working-class solidarity that challenged capitalist relations of production. The primary beneficiaries of this regime were craft unions which represented a small fragment of the labour market that was predominantly male and Anglo. Semi-skilled and especially ethnic and racialized workers were most likely to be the targets of the coercive side of state power.

${ }^{14}$ W. M. Baker, "The Miners and the Mediator: The 1906 Lethbridge Strike and Mackenzic King," Labour/Le Travail, 11 (1983), 89-117.

${ }^{15}$ Ben M. Selekman, Postponing Strikes (New York 1927); Jeremy Webber, "The Mediation of Ideology: How Conciliation Boards, Through the Mediation of Particular Disputes, Fashioned a Vision of Labour's Place within Canadian Socicty," Law in Context, 7, 2 (1989), 1-23. 
State support for the centrality of market mechanisms in the determination of conditions of employment was also reflected in the modest changes to minimum standards legislation during this period. One apparent exception was hazardous working conditions which increasingly came to be regulated by provincial statutes. These laws also continued to limit hours of work for women and young adults and to prohibit the employment of children. As in the past though, the effect of these interventions was limited by weak enforcement and the predominant view that enlightened profit-seeking employers would discover that meeting the legislative requirements was in their economic self interest. In part, this was true because inspectors were loath to require employers to adopt measures that were uneconomical. As a result, divergence between state-established minimum standards and market outcomes was minimized. As well, household and agricultural workers were still denied any legislative protection, reflecting the continued unwillingness of the state to intervene in the domestic sphere, even when relationships within it were established and governed through contracts of employment. ${ }^{16}$

Compensation for work-related injuries, diseases, and fatalities was also contentious. Common law judges had constructed a legal presumption that workers voluntarily assumed the risk of being injured by hazards present in the workplace in exchange for their wages. This kind of market justice was unacceptable to workers and was legislatively modified in the 19th century, but these reforms still made the receipt of compensation dependent either on workers bargaining for disability insurance or proving in court that employer negligence-caused their injuries. Workers continued to demand compensation for their injuries as a matter of justice and employers were unhappy with a system that required them to purchase private insurance, produced litigation conducted by insurance carriers to protect their own interests, and left employees disgruntled. A no-fault system of public insurance offered employers predictability and the de-politicization of work injuries by making them a routine cost of production for which no blame was assigned. For workers, it provided secure compensation. Despite serious disagreements about the terms on which compensation would be awarded and the administration of the scheme, there was enough common ground and political support to establish no-fault, state-administered workers' compensation systems in most provinces, beginning with Ontario in $1914 .^{17}$

As with other minimum standards, though, workers' compensation was carefully tailored to minimize its interference with the market and the normative family. Compensation was set as a percentage of eamings (initially 55 per cent), without

${ }^{16}$ Eric Tucker, Administering Danger in the Workplace (Toronto 1990).

17 R.C.B. Risk, "'This Nuisance of Litigation': The Origins of Workers' Compensation in Ontario," in D.H. Flaherty, ed., Essays in the History of Canadian Law, Vol. II (Toronto 1983), 418-91. Other provinces enacted legislation as follows: Nova Scotia (1915); British Columbia and Manitoba (1916); Alberta and New Brunswick (1918); Saskatchewan (1928); Québec (1931); P.E.I. (1949); and Newfoundland (1950). 
any guarantee of a minimum payment that would keep low wage earners and their dependent families out of dire poverty. Widows, even those with dependent children, lost their pension if they re-married and widowers were only entitled to a pension if they were incapable of working. As well, domestic and agricultural workers were typically excluded.

There was little other protective legislation. Trade unions supported legislated limits on the length of the working day, but only in British Columbia, where labour-supported MLA's sometimes held the balance of power in a particularly fractious legislature, were eight-hour laws passed for underground miners, stationary engineers employed in metal mines, and smelter workers. Progress was aided by the health and safety dimension of the issue. The problem of low-wages for women, and more generally, for all workers who lacked bargaining power, was not addressed legislatively in any province, although some governments promulgated fair wage resolutions that secured workers on government contracts prevailing local wage levels. ${ }^{18}$

If special protection for women was a double-edged sword because it helped reproduce labour market discrimination by entrenching ideas about women's greater physical and moral vulnerability in the workplace, legislative restrictions aimed at Asian workers did not in any way purport to be for their benefit. Rather, these were motivated by a combination of white workers' fear about unfair wage competition and racist beliefs. Legislation restricting the employment of Asian workers was most common in British Columbia, the province with the greatest Asian population. Nineteenth-century statutes banned Chinese and Japanese from underground mining, but from 1899 onwards such laws were either struck down by the courts or disallowed by the Federal government because they interfered with the importation of Asian labour to build the railways and supply the CPR with coal and ran afoul of imperial British policy. A more widespread brand of anti-Asian legislation, ostensibly aimed to protect white women workers from the depredations of Asian employers, passed constitutional muster. ${ }^{19}$

In sum, the legal tegulation of employment in this period tended to constitute and reinforce a market-based model of wage determination in which individual rights of property and contract took priority over the freedom of workers to act collectively. Responsible trade unions that agreed to operate within the narrow

${ }^{18}$ Harold Fabian Underhill, "Labor Legislation in British Columbia," PhD Thesis, University of California, 1935, 97-106; Linda Kealey, Enlisting Women, 29-37; Robert McIntosh, "Swcated Labour: Female Needleworkers in Industrializing Canada," Labour/Le Travail, 32 (1993), 105-38.

${ }^{19}$ Ross Lambertson, "After Union Colliery: Law, Race, and Class in the Coalmines of British Columbia," in Hamar Foster and John McLaren, eds., Essays in the History of Canadian Law, Vol. VI, British Columbia and the Yukon (Toronto 1995), 386-422; Constance Backhousc, "The White Women's Labor Law: Anti-Chinese Racism in Early Twenticth-Century Canada," Law \& History Review, 14 (1996), 315-68. 
confines of industrial legality could be accommodated within this regime, but not those who insisted on challenging the legally constituted rules of engagement. The male and largely Anglo craft fragment of the labour force was more likely to fall in the first category and the much larger industrial fragment into the second. It was only when market outcomes potentially outraged public standards of decency that the state evinced any willingness to impose minimum standards, particularly when paternalist values protecting honest womanhood and the normative family were at stake, or when racialized workers were constructed as the source of danger. But even then, protective legislation or, for that matter, legislation discriminating against racialized workers, was rarely allowed to impede important economic interests.

\section{World War I Labour Policy, 19/4-19/8}

World War I set in motion a chain of events that challenged the regime of industrial voluntarism, including its underlying gender order. Fuelled by tight labour markets, high inflation, and a growing sense of entitlement encouraged by political leaders' claim that this was a war for democracy, workers became increasingly radicalized and militant. The ensuing workers' revolt tested the limits of the legal framework and judges and politicians worked together to defend it. Some state officials, however, were convinced that a new regime was required to accommodate the legitimate demands of working men and women, and they took steps to better institutionalize collective bargaining and strengthen minimum standards (especially for women). Employers resisted these measures and were able to defeat or limit severely many of these initiatives. As a result, although the war and immediate post-war agitation left some imprint on the regime of industrial voluntarism, it survived largely intact for the remainder of the $1920 \mathrm{~s}^{20}$.

The War Measures Act centralized power in the federal cabinet, allowing it to rule by order in council. Initially, the government's labour policy relied on the existing regime to maintain war production. It extended the $I D I A$ to all war industries in 1916, despite the opposition of the dominant labour federation, the Trades and Labour Congress (TLC), which favoured the adoption of a fair wages policy. As the war progressed, however, these tools to contain rising labour militancy failed, and the Federal govermment experimented with a variety of increasingly interventionist responses. ${ }^{21}$

${ }^{20}$ Sec generally Craig Heron and Myer Siemiatycki, "The Great War, the State, and Working-Class Canada," in Craig Heron, ed., The Workers' Revoll in Canada 1917-1925 (Toronto 1998), 11-42; Myer Siemiatycki, "Labour Contained: The Defeat of a Rank and File Workers' Movement in Carada 1914-1921," PhD Thesis, York University, 1986.

${ }^{21}$ Myer Siemiatycki, "Munitions and Labour Militancy: The 1916 Hamilton Machinists" Strike," Labour/Le Travailleur, 3 (1978), 131-151. 
There were some attempts to accommodate the demands of responsible unions and better institutionalize collective bargaining with them. For example, state intervention prevented coal strikes in Nova Scotia by helping to secure an agreement that included union recognition and a dues check-off. On the railways, the government pressured the parties to establish a scheme of consensual, binding interest arbitration. As well, it actively sought a rapprochement with the TLC leadership in the hope that its more responsible leaders would help to contain the rising conflict. In January, 1917, Gideon Robertson, an officer with the railway telegraphers' union, was appointed to Senate and to Cabinet as a minister without portfolio with responsibility for labour matters. Trade union representatives were subsequently appointed to various government councils and commissions. Many provinces also took a slight corporatist tum, creating or expanding labour bureaux or departments. ${ }^{22}$

More militant unions and labour radicals faced a more coercive response, especially after the 1917 Bolshevik revolution. The state security apparatus was strengthened and it cracked-down on IWW agitators and other "undesirable," often foreign-bom, radicals. In April 1918, the government issued PC 815 that made it an offence for an adult male not to be "regularly engaged in a useful occupation," and PC 915 that further restricted public expression of anti-war sentiment. ${ }^{23}$

- Still, the government's primary response to labour unrest remained conciliatory. Indeed, that summer, the government issued PC 1743, a declaration of its war labour policy, which recognized the right of workers to join a union without employer interference or retaliation; supported the maintenance of union shops established by agreement; and endorsed the idea that all workers were entitled to a living wage sufficient to support themselves and their families in decency and comfort. In exchange, it called for no strikes or lockouts for the duration of the war and respect for the right of individual workers to refrain from joining a union. This order, however, was merely declaratory of the government's policy; no steps were taken to implement it.

Only in the very last days of the war did federal labour policy veer sharply towards coercion. In September 1918, the government issued orders banning enemy language publications and proscribing unlawful associations, and finally, in October, it banned strikes and lock-outs for the duration of the war. The signing of the armistice the following month, however, largely avoided the need for the govern-

${ }^{22}$ Paul MacEwan, Miners and Steelworkers (Toronto 1976), 39-53; David Frank, "The Cape Breton Coal Miners, 1917-1926," PhD Thesis, Dalhousie University, 1979, 297-30 I; Slephen G. Peitchinis, "Labour-Management Relations in the Railway Industry," Task Force on Labour Relations, Study No. 20, (Ottawa 1971), 101-12; Allen Seager, "A new labour era?': Canadian National Railways and the railway worker, 1919-1929," Journal of the Canadian Hisiorical Associalion, 3 (1992), 171-95; James Foy, "Gideon Robertson: Conservative Minister of Labour 1917-1921," MA Thesis, University of Ottawa, 1972.

${ }^{23}$ Gregory S. Kealey, "State Repression of Labour and the Left in Canada, 1914-20: The Impact of the First World War," Canadian Historical Review, 73 (1992), 281-314. 
ment to resolve how it would enforce the ban, and, in general, left open the question of whether the government could successfully operate a dual labour policy which simultaneously promoted the institutionalization of responsible unionism and repressed labour radicalism.

The war also challenged the gender order of the second industrial revolution in which families' access to the means of survival was primarily through a male wage, and in which female wage eamers were restricted to a limited number of lower paying jobs. Conscription deprived many families of their breadwinners and the ensuing labour shortage also drew some women into men's jobs. This situation raised in a particularly sharp manner the dual problem of low female wages; they were insufficient to support a household and undercut men's wages.

One means of minimizing downward pressure on male wages was to promote equal pay for women doing work ordinarily performed by men. The government formally embraced the principle in PC 1743, but most employers resisted the practice. The problem of low wages for the mass of women employed in women's jobs began to be addressed in 1917 by provincial female minimum wage legislation. Minimum wage boards were empowered to set female wages on an occupational basis, but instead of adopting an egalitarian approach, they took a protective one which, at best, provided working women with the bare minimum needed to reproduce their own labour. This idea of the minimum contrasted sharply with the "fair" or "living" wage principle that was embraced by $I D I A$ boards and the federal and some provincial govemments in their contracting practices. As a result, with the end of the war, fragmented labour markets reasserted themselves and women were once again confined to low wage work, even while the principle of state-established minimum standards for especially vulnerable labour force participants was further entrenched. ${ }^{24}$

\section{The Defeat of the Post-War Workers ' Revolt, 1918-1929}

The end of the war did not bring labour peace but heightened conflict. Workers sought to obtain more democracy and prosperity at home, having sacrificed to protect it abroad, while employers sought to restore the status quo ante, having made concessions under the pressure of tight labour markets and government pressure to maintain war production. The Federal government stood between labour and capitai, but was not a neutral umpire. Its primary objective was to maintain social order and economic growth within a capitalist framework. As before, this

${ }^{24}$ Bob Russell, "A Fair or a Minimum Wage? Women Workers, the State, and the Origins of Wage Regulation in Western Canada," Labour/Le Travail, 28 (1991), 59-88; Linda Kealey, "Women and Labour during World War I: Women Workers and the Minimum Wage in Manitoba," in Mary Kinnear ed., First Days, Fighting Days (Regina 1987), 76-99; Margaret McCallum, "Keeping Women in Their Place: The Minimum Wage in Canada, 1910-25," Labour/Le Travail, 17 (1986), 29-56; Ceta Ramkhalawansingh, "Women during the Great War," in Women at Work (Toronto 1974), 261-307. 
required a mixture of conciliation and coercion, although disagreement emerged over the appropriate blend. ${ }^{25}$

In the immediate aftermath of the Armistice, the government continued both to construct an accord between responsible unions and employers and to contain manifestations of political and labour radicalism. Prime Minister Borden played an active role in drafting the labour sections of the Treaty of Versailles that established the International Labour Organization (Iio) and endorsed the principle of workers' freedom of association. The government also appointed the Royal Commission on Industrial Relations (RCIR) to inquire into means of improving relations between employers and workers. At the same time, however, it introduced amendments to the Immigration $\mathrm{Act}$ expanding its powers to prohibit radicals from entering the country and making it easier to deport them. It also embarked on the process of amending the Criminal Code to broaden the definition of sedition and ban unlawful associations.

Labour conflict reached unprecedented levels in the spring of 1919 , much of it led by radicalized workers who split from the more conservative TLC to join the One Big Union (OBU). While the revolt was national in its dimensions, the centre of conflict was in Winnipeg where a general strike of some 30,000 workers began on 15 May and lasted until 26 June. The Federal government was determined that the strike must fail and it worked closely with the local bourgeoisie to achieve that result. After it became apparent that the strike would not collapse on its own accord, police arrested strike leaders. The British-bom were charged with seditious conspiracy while the foreign-born were dealt with under the Immigration Act with the expectation that they would be deported. Following the arrests, strike supporters held a rally in defiance of a ban on public demonstrations and, after the crowd failed to disperse, police opened fire, killing two men and wounding many others. ${ }^{26}$

After the strike's defeat, the criminal trials of the British-born strike leaders became a cause célébre. A judge sympathetic to the prosecution presided and most of the leaders were convicted and sentenced to terms of imprisonment that ranged from six months to two years. Ironically, the 'forcign'-borm leaders fared better in

\footnotetext{
${ }^{25}$ See essays in Heron, Workers 'Revolt.

${ }^{26}$ David J. Bercuson, Fools and Wise Men (Toronto 1978); A. Ross McCormack, Reformers, Rebels and Revolutionaries (Toronto 1997); Gregory S. Kcaley, "1919: The Canadian Labour Revolt," Labour/Le Travail, 13 (1984), 1 1-44; David J. Bercuson, Confrontation at Winnipeg, rev. ed. (Montrćal 1990); D.C. Masters, The Winnipeg General Strike (Toronto 1950); Noman Penner, ed., Winnipeg 1919, 2nd ed., (Toronto 1975); Tom Mitchell, "“To Reach the Leadership of this Revolutionary Movement': A.J. Andrews and the Suppression of the Winnipeg General Strike," Prairie Forum, 18 (1993), 239-55; Chad Reimer, "War, Nationhood and Working-Class Entitlement: The Counterhegemonic Challenge of the 1919 Winnipeg General Strike," Prairie Forum, 18 (1993), 219-37.
} 
administrative proceedings: only one was ultimately deported and the rest were set free. Some of the less prominent aliens, however, were secretly deported. ${ }^{27}$

Significant outbursts of radicalism in other parts of the country atso met with extraordinary assertions of state power. For example, in the Alberta coalfields, where there was an OBU breakaway from the more conservative United Mineworkers of America (UMWA), the state-appointed director of coal operations made a closed shop agreement between the UMWA and the coal operators legally enforceable. When the legality of the order was questioned, the federal government retroactively ratified it by statute. Meanwhile, in Nova Scotia, J.B. MacLachlan, leader of a radicalized local district of the UMWA, was convicted of seditious libel and sentenced to two years imprisonment. ${ }^{28}$

The exercise of coercive force to defeat the post-war labour revolt was not accompanied by an abandonment of the state's efforts to institutionalize an accord between responsible unions and employers. However, the overwhelming majority of employers had no interest in pursuing a partnership with organized labour, even if unions behaved responsibly. They preferred neo-paternalist employee representation schemes that excluded independent unions. Because the government was reluctant to compel unwilling employers to accept independent trade unions, its efforts at a rapprochement collapsed. The election of the Liberals in 1921, led by Mackenzie King, the architect of pre-war industrial voluntarism, ended the federal govemment's attempt to constnuct a new national labour relations policy. ${ }^{29}$

The institutional and ideological reconstruction of the labour market as local and consensual ultimately had constitutional significance. Under the constitution, provinces had jurisdiction over property and civil rights, while the federal govern-

${ }^{27}$ Tom Mitchell, "Repressive Mcasures": A.J. Andrews, the Committee of 1000 and the Campaign Against Radicalism After the Wimnipeg General Strike," Left History, 3, 2 and 4,1 (1996), 133-167; Desmond H. Brown, "The Craftsmanship of Bias: Sedition and the Winnipeg Strike Trial, 1919," Manitoba Law Journal, 14 (1984), 1-33; Leslie Katz, "Some Legal Consequences of the Winnipeg General Strike of 1919," Manitoba Law Journal, 4 (1970-71); 39-52.

${ }^{28}$ Charles Allen Seager, "A Proletariat in Wild Rose Country: The Alberta Coal Miners, 1905-1945," PhD Thesis, York University, 1981, 316-61; Bercuson, Fools and Wise Men, 136-43; Foy, "Gideon Robertson," I12-17; Frank, "The Cape Breton Coal Miners," and "The Trial of J.B. McLachlan," CHA Historical Papers, (1983), 208-25; John Manley, "Preaching the Red Stuff: J.B. McLachlan, Communism, and the Cape Breton Miners, 1922-1935," Labour/Le Travail, 30 (1992), 65-114; Barry Cahill, "Howe (1835), Dixon (1920) and McLachlan (1923): Comparative Perspectives on the Legal History of Sedition," University of New Brunswick Law Journal, 45 (1995), 281-307.

${ }^{29}$ Royal Commission on Industrial Relations, "Report of Commission" (Ottawa: Supplement to Labour Gazette, July 1919); Larry G. Gerber, "The United States and Canadian National Industrial Conferences of 1919: A Comparative Analysis," Labor History, 32 (1991 ), 42-65; Margaret McCallum, "Corporate Welfarism in Canada, 1919.39," Canadian Historical Review, 71 (1990), 46-79. 
ment had authority over national trade and commerce, criminal law and peace, order, and good government. A challenge to the constitutionality of the $I D I A$ in the midst of the 1913 strike wave failed when the court held that the act was "not legislation affecting private or civil rights" but rather protected the broad public interest in peace, order, and good government. When the IDIA was challenged after the war, most Canadian judges agreed with this view. However, the Privy Council of the House of Lords, the final court of appeal, disagreed. It held that labour relations was a matter of property and civil rights, thereby sharply curtailing federal jurisdiction. Although this was not the result that King's govemment desired, it was not radically inconsistent with the prevailing Liberal view about the limited role of the national government. ${ }^{30}$

The decentralization of labour law and policy allowed for more localized responses to particular conditions, but in practice little changed. The old coercive infrastructure of voluntarism (justified as the protection of individual rights of property and contract) remained in force and continued to be applied with particular vigour against the few militant unions that survived the immediate post-war defeats. In Nova Scotia, for example, local officials requisitioned troops during strikes by Cape Breton coal miners and steel workers in 1922, 1923, and 1925. Labour injunctions also became more common as many judges held that it was necessary to curb picketing in order to protect the rights of employers, individual employees, and members of the public. These limitations on picketing remained imprecise and different judges held competing views on the question. Still, the threat of liability was ever-present, even for responsible unions, and the TLC lobbied unsuccessfully for legislation that would unambiguously permit peaceful picketing and limit trade union liability for damages arising out of strike-related activity. ${ }^{31}$

Provinces did not enthusiastically embrace their new jurisdiction. Instead, most took advantage of federal legislation that enabled them to make the $I D I A$ apply to mining, railway, and public utility disputes within their jurisdiction. The only legal innovations were in Nova Scotia and Québec, where concessions were made in order to promote more conservative unions and avoid incursions by less desirable ones. In Nova Scotia, where the UMWA was fighting off the communist-influenced Mine Workers Union of Canada (MWUC), the Coal Mine Regulation Act was amended in 1927 to make union dues deductions mandatory when requested in writing by an employee. This was subsequently used by the UMWA to enforce closed

\section{${ }^{30}$ Toronto Electric Commissioners v. Snider [1925] A.C. 396.}

${ }^{31}$ Don Macgillivray, "Military Aid to the Civil Power: The Cape Breton Experience in the 1920s," Acadiensis, 3, 2 (1974), 45-64; David Frank, "Class Conflict in the Coal Industry Cape Breton 1922," in Gregory \$. Kealey and Peter Warrian, eds. Essays in Canadian Working Class History (Toronto 1976), 161-84; and Frank, "Cape Breton Coal Miners," 362-75; Craig Heron, Working in Steel (Toronto 1988), ch. 4; Steven Penfold, "Have You No Manhood In You?': Gender and Class in the Cape Breton Coal Towns, 1920-1926," Acadiensis, 23, 2 (1994), 21-44; Seager, "Proletariat," 362-423. 
shop agreements against MWUC members. In Québec, a Catholic trade union movement emerged that was committed to the church's social teachings which emphasized cooperative relations between workers and employers. The Professional Syndicates Act passed in 1924 permitted workers to form incorporated associations that were able to enforce collective agreements and shield their benefit funds from seizure by employers seeking to enforce damage awards. While the Act did not directly limit participation in the scheme to Catholic unions, it did so indirectly by requiring that to incorporate all directors had to be British subjects and that foreigners could only constitute up to one-third of the membership. This clearly disqualified international unions which were, in any event, ideologically opposed to incorporation, seeing it as a means of subjecting them to more extensive legal control. The provincial government's support for Catholic unions, however, only went so far. There was nothing in the scheme that compelled employers to recognize or bargain with incorporated unions. ${ }^{32}$

Overall, the coercive infrastructure of the post-war regime of industrial voluntarism applied to all workers, although its enforcement varied considerably. Conciliatory law was far more fragmented. The coverage of the IDIA was patchy, provincial trade dispute legislation was purely voluntary, and the frequency and effectiveness of $a d$ hoc interventions by state officials varied enormously. Given this legal regime, the level of employer resistance, and the weakness of Canadian unions, collective bargaining in the 1920 s was confined to a small segment of the labour market, benefiting a minority of mostly male, mostly Anglo workers.

For the majority, there were few minimum standards to protect against unfavourable labour market conditions and discriminatory practices. Provincial female minimum wage laws typically covered women employed in factories, shops and offices, but excluded those in rural areas and donestic service. The boards that administered these laws did not challenge labour market discrimination that denied most women access to "fair" or equal wages. Moreover, these laws also reinforced industrial and sectoral fragmentation. Instead of setting a flat rate, the boards set different rates for different industries, taking into account specific business conditions. In addition, further rate distinctions were based on age and experience. In sum, the boards" practices reinforced labour market fragmentation. ${ }^{33}$

${ }^{32}$ William Steward Amold Martin, "A Study of Legislation Designed to Foster Industrial Peace in the Common Jurisdiction of Canada," PhD Thesis, University of Toronto, 1954, 263-72. Frank, "Cape Breton Coal," 376-82; Jacques Rouillard, Histoire du Syndicalisme Quebécois (Montréal 1989), 120-29, 169-70; History of the Labour Movement in Quebec (Montréal 1987), 90-94.

${ }^{33}$ J.W. Macmillan, The Limits of Social Legislation (Toronto 1933), 30; Kathleen Derry and Paul H. Douglas, "The Minimum Wage in Canada," Journal of Political Economy, 30 (1922), 155-88; Kealey, Enlisting Women, 169-175; McCallum, "Keeping Women," 42-56; Russell, "A Fair or Minimum," 80-88. 
Wage inequality was not the only legally countenanced form of sex discrimination; governments also supported the re-entrenchment of labour market segregation in the post-war reconstruction period. For example, a veterans' preference clause was inserted into the federal govemment's Civil Service Act in 1918 and, in 1921, during a period of high unemployment, formal restrictions were placed on the employment of married women. In practice, these laws did not exclude women from the federal civil service, but they helped channel them into poorly paid occupational ghettoes. ${ }^{34}$

British Columbia was the only province that legislated maximum hours of work and minimum wages for men. Eight-hour laws had been passed in the pre-war era for underground miners and some related employees, but it was only in 1923, largely in response to fear of unfair wage competition from workers of Asian origin, that a law of more general application was enacted, covering mining, manufacturing, and construction. This was followed in 1925 by the passage of male minimum wage legislation that, again, was largely driven by anti-Asian sentiment. Employers challenged the law and convinced a court that it required wages be set job by job, not by occupation. This rendered the statute completely ineffective. ${ }^{35}$

\section{The Final Crises of Industrial Voluntarism, 1929-45}

The social and labour market disruptions resulting from the Great Depression and World War II undermined the foundation upon which industrial voluntarism was reconstructed in the post-World War I era. Several strike waves and political and ideological realignments produced a qualitatively different regime (commonly known as industrial pluralism), albeit one that bore the imprint of its predecessor and the struggles that marked its demise. Although these crises created the possibility of producing a less fragmented legal regime, in the end fragmentation increased, enhancing gaps between differently situated workers.

At the height of the Great Depression nearly one quarter of the labour force was unemployed and double-digit unemployment persisted for the remainder of the decade. Many of those lucky enough to be employed faced declining standards of living, as neither trade unions nor minimum standards laws were strong enough to protect workers from the downward pressure on wages. The state's response to the resulting human suffering, especially in the first and most critical years, was grossly inadequate. Federal relief failed to meet the needs of families, and single unemployed women and men were commonly denied relief altogether. ${ }^{36}$

${ }^{34}$ Judy Fudge, "Exclusion, Discrimination, Equality and Privatization: Law, The Canadian Statc and Women Public Servants, 1908-2000," (forthcoming), 7.

${ }^{35}$ The exception was a 1917 amendment to the Alberta Factories Act providing that all persons employed in factories, shops and offices were entitled to a $\$ 1.50$ per shift. On the British Columbia legislation, sce Underhill, "Labor Legislation," 133-67.

${ }^{36}$ John Herd Thompson with Allen Seager, Canada 1922-1939 (Toronto 1985), 193-252; James Struthers, No Fault of Their Own: Unemployment and the Canadian Welfare State 
In this climate, radicalism flourished, among the employed, who resisted immiseration, and the unemployed, especially single men who were uprooted from their communities and later funnelled into relief camps established by the federal government. The Communist Party played a particularly active role in organizing both groups through the Workers' Unity League (WUL) and the Relief Camp Workers' Union ( $\mathrm{RCWU}$ ). The state responded with increased surveillance and repression. Leaders of the party were arrested in 1931 and convicted under the infamous section 98 for being members of an illegal organization. Strikes by wuL-affiliated unions in Anyox, British Columbia, Estevan, Saskatchewan, Flin Flon, Manitoba, Stratford, Ontario, and Rouyn, Québec were defeated by stiff employer resistance, bolstered by the armed force of the state and a sympathetic judiciary. The bloody police attack in Regina that terminated the 1935 On-toOttawa trek of unemployed workers represented the high point of this coercive turn. ${ }^{37}$

However much the federal government wanted to blame this unrest on a small band of radical agitators, it could not escape the reality of widespread human suffering and the sympathy this generated in the broader community. A last minute and poorly conceived attempt to launch a Canadian New Deal failed to save the federal Conservative government in 1935, but the election of King's Liberals did not produce a dramatic change in government policy.

The absence of a federal New Deal left the field open to the provincial governments which were being pressured on many fronts. Politically, the Co-operative Conntonwealth Federation (CCF) attracted substantial working-class and farmer support, threatening established political parties. As well, unorganized industrial workers became increasingly militant and evinced a willingness to violate their employers' legal rights by, for example, occupying factories in support of their demands. Many provincial officials also were becoming convinced that low wages were part of a vicious cycle of weak demand and excess competition that depressed the economy and placed a heavy burden on state coffers. No longer was it a vulnerable minority (predominartly female) that needed protection from the vicissitudes of the market; the problem was endemic.

Provincial governments responded to these challenges in a variety of ways. On the one hand, governments made it clear that violations of the law would not be tolerated and the sit-down movement in Canada was short-lived. As in the past,

19/4-194/ (Toronto 1983), ch. 2; Barry Broadfoot, Ten Lost Years 1929-1939 (Markham 1975).

${ }^{37}$ Lome Brown, When Freedom Was Lost (Montréal 1987); John Manley, "Communism and the Canadian Working Class During the Great Depression: The Workers' Unity League," PhD Thesis, Dalhousie University, 1984; Steve Hewitt, "September 1931: A Re-Interpretation of the Royal Canadian Mounted Police's Handling of the 1931 Estevan Strike and Riot," Labour/Le Travail, 39 (1997), 159.78; Jean-Michel Catta, La grève des bucherons de Rouyn, 1933 (Rouyn 1985). 
threats to employers' property and contract rights evoked a strong state response, although the Criminal Code was unexpectedly amended in 1934 to restore the right to picket peacefully. On the other hand, governments felt pressured to address some of the underlying sources of labour discontent. The resulting initiatives varied from province to province, depending on local conjunctures of interests and ideologies, but essentially they extended trade union rights and minimum standards. This entailed departures from the norms of industrial voluntarism by limiting employers' freedom of contract and requiring the creation of a larger administrative apparatus.

Much of the post-1935 strike activity took place under the banner of the newly established, American-based, Congress of Industrial Organization (CJO). Trade-union organizing in the United States was given a shot in the arm by the Wagner Act (1935) which prohibited employer interference with trade union organization, required employers to recognize and bargain with trade unions that had majority support, and created an administrative body vested with the legal authority to enforce the scheme. In Canada, however, the craft unions that dominated the TLC were wary of that model, fearing that it would support industrial unions at their expense. Hence, the TLC refused to campaign for a Canadian version and instead, in 1936, drafted a model bill that prohibited various kinds of employer interference with the right of workers to join trade unions and bargain collectively.

In the following years, some version of the TLC bill was passed by nearly every province, except Ontario, where Premier Mitch Hepburn's fear and loathing of the clo blocked any such move. This legislation limited empioyers' freedom of contract by, for example, making it a provincial offence, punishable by fine, for employers to require that workers agree not to join a trade union as a condition of their employment. By 1939, the federal government also became involved and made it a crime to refuse to employ a person for the sole reason that the person was a member of a lawful trade union formed for the purpose of advancing in a lawful manner their interests.

In some provinces, freedom of association was part of a larger package of reforms. For example, Manitoba and New Brunswick also enacted IDIA-type legislation that was applicable to provincial labour disputes, while Nova Scotia, Alberta, and British Columbia passed stripped-down versions of the Wagner Act. Only in Nova Scotia was the law used successfully. Elsewhere it had no impact, in part because enforcement was through prosecution in the courts, rather than through an administrative tribunal equipped with the remedial power to implement the law effectively and efficiently. As a result, prior to World War II collective bargaining spread slowly in the mass production industries.

The most interesting legislative innovation during this period was the enactment of industrial standards acts that conjoined collective bargaining with minimum standards to construct a framework for joint labour-management regulation of labour markets capable of resisting downward pressure in intensely competitive local markets. Inspired by Roosevelt's National Industrial Recovery Act, such 
schemes provided that an agreement reached between a group of workers and employers within a particular industrial sector and geographic region could become binding on all employers and workers in that sector and region even though they were not parties to the agreement. The law facilitated collective bargaining in highly competitive sectors by assuring employers who saw the benefit of cooperation, that they would not be disadvantaged by those who did not. Statutes along these lines were passed in Québec (1934), Ontario and Alberta (1935), Nova Scotia (1936), Saskatchewan (1937), Manitoba (1938), and New Brunswick (1939). Their major weakness was that there was no way to compel employers to participate and so industrial standards were only established in a few sectors, most notably construction and some branches of the garment industry, where employers saw a benefit from joint regulation. Another problem was that such schemes tended to reinforce fragmentation on a gendered basis; the wage schedule that was negotiated in the garment industry placed women at the bottom of an artificially constructed, gendered hierarchy of skill. ${ }^{38}$

The limited gains on the collective bargaining front left the vast majority of workers to fend for themselves through their individual contracts of employment. For many the result was unacceptably low wages, a consequence that provincial governments felt compelled to address not only for electoral reasons but to support macro-economic policies aimed at increasing demand, reducing industrial conflict, and relieving the strain on welfare budgets. The form of intervention was contested though and each province tended to follow a somewhat different path.

Since many women were already covered by minimum wage laws, in most provinces the issue was whether to extend minimum wages to men and, if so, on what basis. A few of the earliest Depression-era minimum standard laws were sector specific, including a number directed at the forestry industry. Between 1934 and 1937, all provinces except Nova Scotia enacted a general male minimum or fair wage law. Following the precedent of female minimum wage laws, they did not establish a flat rate, but rather empowered administrative bodies to establish industry- and geographic-specific minima. Typically, the statutes provided for conferences or consultations to be held in an effort to obtain voluntary agreement. Absent of an agreement, however, the schemes provided that a schedule of wages could be imposed by order. Most of these administrative bodies also were empowered to set maximum hours of work.

Beyond these basic similarities, the schemes varied considerably. Manitoba and Saskatchewan simply extended their female minimum wage laws to men, so that there were no differences between the minimum male and female wage rates. British Columbia and Alberta enacted separate male minimum wage laws and

${ }^{38}$ Steedman, Angels of the Workplace, ch. 7 and "Canada's New Deal in the Needle Trades," Relations Industrielle, 53 (1998), 535-61; Mark Cox, "The Limits of Reform: Industrial Regulation and Management Rights in Ontario, 1930-7," Camadian Historical Review, 68 (1987), 5\$2-75. 
issued separate orders that provided for a higher male minimum wage. Ontario enacted a consolidated minimum wage law in 1937, but the only order issued by the end of the decade set a lower wage rate for women than for men in the textile industry. Québec's fair wage law was the most extensively applied. A general order set wages for most categories of work in towns and municipalities, without a male/female differential. In nural areas, the earlier female women wage orders were adopted and extended to men performing the same duties as women. 39

In sum, the regime of industrial voluntarism and its legitimating ideology began to unravel in the face of the social, economic, and political disorder caused by the Great Depression, leading to an expanded role for the state in regulating employment. This entailed restrictions on employers' freedom of contract to create a protected space for trade union activity and to guarantee that wages and some other conditions of employment did not fall below a socially acceptable level. These changes, however, had minimal impact. Collective bargaining spread slowly and little of its progress could be attributed to a more favourable legal climate. For the rest, a regime of individual contract prevailed, subject only to a few legislated standards. Minimum wage laws respected industrial and regional differences. In some provinces, differential male/female wage rates were directly enshrined in law, while in others, discrimination was indirectly inscribed by assigning lower wage rates to femalc-dominated occupational categories. These differences, however, were small - rarely more than ten per cent - because employers resisted paying higher wages to men, despite their breadwinner status. Finally, employment legislation of all kinds was poorly enforced.

World War II produced the second set of crises that ultimately brought about the demise of industrial voluntarism and its replacement by a new regime of industrial legality. As in the case of World War $I$, the federal government invoked its emergency powers to rule by order in council. Domestically, its primary objectives were to maximize war production and control inflation. To that end, it recruited leading industrialists into key govemment departments, kept organized labour frozen out of the inner circles, and adopted World War I precedents as war labour policy. ${ }^{40}$

The recruitment of women into the labour force was a priority for government, but concern about maintaining male breadwinner privilege shaped the pattern of

${ }^{39}$ William Parenteau, "Forest and Society in New Brunswick: The Political Economy of the Forest Industries, 1918-1939," PhD Thesis, University of New Brunswick, 1994, 386-425; Catta, Grève des bücherons, 51 -64; Ian Radforth, Bushworkers and Bosses (Toronto 1987), 130; A.E. Grauer, Labour Legislation (A Study Prepared for the Royal Commission on Dominion-Provincial Relations, Ottawa, 1937), 28-47, 94-102; Catherine Briggs, "Women, Men and the Minimum Wage in Ontario 1916-1940," MA Thesis, University of Guelph, 1992.

${ }^{40}$ Laurel Sefton MacDowell, "The Formation of the Canadian Industrial Relations System During World War Two," Labour/Le Travailletur, 3 (1978), 175-96. 
their entry. The overwhelming majority of women were employed in traditional female occupations, but even those recruited into war industries were segregated into certain occupations and government policy enabled employers to re-classify jobs by creating lower-paid categories for less experienced women and youth. This segregation helped to keep women out of much of the industrial organization that occurred during the war. ${ }^{41}$

The federal government's industrial relations policy strengthened its capacity to coerce and conciliate. The Defence of Canada Regulations did not specifically target trade unionists, but officials used it to detain leading industrial unionists, often at key points in strikes. Indeed, by 1941 the government felt compelled to curb over-zealous officials by amending the Regulations to stipulate that peaceful picketing was not prohibited. Through the Regulations the government banned over thirty organizations including the Commurists. ${ }^{42}$

In addition to coercion, the federal govemment's early war labour policy also promoted peaceful industrial relations through the extension of compulsory conciliation under the IDIA and by the adoption of a statement of principles. The first step brought nearly 85 per cent of Canadian industry under the federal IDIA by 1941 , thereby assuring federal domination of the field. The statement of principles in PC 2685 expressed support for the right of workers to organize and bargain collectively, and for binding arbitration as a means of resolving disputes over the interpretation and application of collective agreements. These principles, however, were not enforceable. ${ }^{43}$

As the war progressed, the govermment's labour policy proved unable to accomplish its goal of maintaining industrial peace and restraining inflation. In the face of growing union militancy, government policy took a coercive tum in 1941. The hurdles that a union had to jump through before it could legally strike were increased, and a policy of prosecuting unlawful strikers was adopted. In December of that year, the government also introduced compulsory wage controls, but these actions did not produce labour peace. The increasing use of compulsion against workers, coupled with the absence of compulsion aimed at employers, made the government's proclaimed support for industrial voluntarism seem hypocritical. Not only did the policy fail to contain rank-and-file militancy, it also was becoming a

${ }^{41}$ Ruth Roach Pierson, "They're Still Women After All": The Second World War and Canadian Womanhood (Toronto 1986); Ellen Scheinberg, "The Tale of Tessie the Textile Worker: Female Textile Workers in Cornwall During World War II," Labour/Le Travail, 33 (1994), 153-86; Anne Forrest, "Securing the Male Breadwinner: A Feminist Interpretation of PC 1003," in Cy Gonick, Paul Phillips, and Jesse Vorst, eds., Labour Gains, Labour Pains: Fiffy Years of PC 1003, (Winnipeg 1995), 139-62.

${ }^{42}$ Reg Whitaker, "Official Repression of Communism during World War II," Labour/Le Travail, 17 (1986), 135.

${ }^{43}$ Russell, Back to Work?, ch. 6. 
political liability as the CCF was beginning to pose a serious electoral threat in a number of provinces. ${ }^{44}$

By the beginning of 1943 political support for compulsory collective bargaining was growing. Ontario, British Columbia, and Alberta enacted provincial laws in an effort to stave off the CCF threat, but it took another year of militant strike action to finally convince King, the architect of industrial voluntarism, that his creation was no longer viable. PC 1003 was unveiled on 17 February 1944 and it contained an amalgam of three distinct elements: compulsory bargaining, compulsory conciliation, and compulsory grievance arbitration. While the first aimed to satisfy union demands, the latter two emphasized the government's goal of limiting industrial conflict by natrowly circumscribing the timing and purpose of strike activity. Moreover, the move to compulsory bargaining was not accompanied by any measures that forced employers to conclude collective agreements. Disagrecments were ultimately resolved by an economic contest of strength. As a result, a kernel of voluntarism resided at the core of industrial pluralism. ${ }^{45}$

\section{Refining the Contours of Industrial Pluralism, 1945-48}

PC 1003 brought the government what it wanted most, relative labour peace for the duration of the war. The shape of the post-war world, however, still needed to be resolved as federal jurisdiction began to wane. Industrial unions pressed to build upon their war-time gains by obtaining union security (both financial and membership), industry-wide bargaining, and significant wage increases. Employers opposed them at every turn and it was through these struggles that the parameters of the post-war settlement were defined.

The Windsor Ford strike in 1945 set a number of important precedents. First, it demonstrated that the state would not deploy massive force to help employers maintain production in the face of overwhelming public support for a strike that aimed to achieve "legitimate" collective bargaining objectives, even though unlawful mass-picketing violated employer rights of property and contract. Second, the Rand formula, which was used to settle the strike, established the normative principle that trade unions were entitled to financial security (but not necessarily membership security) in the form of a dues check-off for all workers in the bargaining unit whether or not they were members of the union. In return, however,

${ }^{44}$ Laurel Sefton MacDowell, 'Remember Kirkland Lake' The Goldminers' Strike of $1941-42$ (Toronto 1983); Jeremy Webber, "The Malaise of Compulsory Conciliation: Strike Prevention in Canada during World War II," Labour/Le Travail, 15 (1985), 57-88.

${ }_{45}$ Judy Fudge and Harry Glasbeek, "The Legacy of PC 1003," Canadian Labour and Employment Law Journal, 3 (1995), 357-99; Aaron McCrorie, "PC 1003: Labour, Capital, and the State," in Labour Gains, Labour Pains, 15-38. 
unions had to behave responsibly by repudiating illegal strikes and disciplining members who participated in them. ${ }^{46}$

While the Rand formula became the hegemonic form of union security, a further wave of strikes was fought to secure higher wages. In this regard, unions had to fight against employer recalcitrance and the federal govenument's declared policy of maintaining wage controls past the war's end. The cro unions initiated a common wage plan that sought to overcome regional and industrial differentials. A series of strikes established industry-wide agreements in steel, rubber, electronics, and a few other major industries, but broader wage solidarity was not achieved. Moreover, these agreements were based on power rather than on right. Both under federal collective bargaining law and in the provincial statutes that were passed as industrial relations returned to provincial jurisdiction, bargaining rights predominantly were granted for a specific workplace and employer. The return to provincial jurisdiction also gave greater scope for the play of regional economic forces, leading to even greater fragmentation.

In sum, the new regime of industrial pluralism underwrote the gains made by industrial unions through the exercise of their economic power in the war and the post-war era, allowing for the spread of collective bargaining to core industrial sectors. Unions in these sectors obtained for their members improved wages and occupationally-based benefits, seniority rights, and protection against arbitrary discipline and discharge. The price was that unions were tightly wrapped up in a web of industrial legality that constrained militancy, recognized management rights, and favoured fragmented bargaining. Moreover, women did not share in the benefits of post-war industrial pluralism equally with men. Rather than seeing their war-time gains consolidated, women (especially married women) faced government policies that pushed them out of the labour market. Those who remained employed were segregated into a relatively small number of occupational categories, often in industries outside the industrial core, and even those who were in unions often were bargained into lower-paid female job classifications. ${ }^{47}$

$\boldsymbol{H}$

III. Industrial Pluralism, 1948-2000

\section{Introduction}

Industrial citizenship, which comprised the freedom of association, the right to representation, and the rule of law, was the crowning achievement of industrial pluralism. By substituting legal right for industrial might in order for workers to insist that their employers recognize and bargain with their unions and abide by

${ }^{46}$ David Moulton, "Ford Windsor 1945," in Irving Abella, ed., On Strike (Toronto 1975), 129-61.

${ }^{47}$ Forrest, "Securing the Male Breadwinner"; Ann Porter, "Women and Income Security in the Post-War Period: The Case of Unemployment Insurance, 1945-1962," Labour/Le Travail, 31 (1993), 111-44; Gillian Creese, Contracting Masculinity (Toronto 1999), 60-70. 
their collective agreements, collective bargaining legislation and grievance arbitration marked a rupture from the individualism of the common law and the absolutism of property rights. The post-war employment law regime also saw the imposition of liberal democratic constraints on freedom of contract and the rights of private property. These constraints took two forms: the enactment of anti-discrimination or human rights legislation and the extension of minimum standards of employment to a wider range of workers and conditions. Prior to World War II, employers were free to discriminate against individuals on the basis of ineluctable characteristics such as race and sex, since individual freedom from state compulsion was regarded as the paramount liberal value. After the Holocaust, this position was no longer tolerable. Moreover, unions endorsed a strategy of incremental legal reform regarding minimum conditions of employment and pushed for restrictions on hours of work, vacations with pay, minimum wages, and improvements to the workers' compensation regimes.

Thus, in many respects labour was no longer treated simply as a commodity; the employment law regime institutionalized decommodified conceptions of justice. Collective bargaining legislation enshrined the democratic commitment to freedom of association, human rights statutes embodied the liberal commitment to fairness and equality, and employment standards acts encapsulated a social understanding of public welfare. However, these competing conceptions of justice did not completely displace liberal voluntarism's commitment to freedom of contract and private property. A residual market voluntarism was the foundation upon which industrial pluralism was built. The operative assumption was that bargaining disputes should ultimately be settled by reference to the economic power of the parties themselves. The privilege to resort to industrial sanctions, the ultimate measure of bargaining power, continued to determine the contents of collective agreements. Moreover, employers could still call upon a sympathetic judiciary, predisposed to the common law's traditional emphasis on respect for individual property and contract rights, for assistance in labour disputes. Employment standards and human rights also operated within a fundamentally liberal voluntarist context. Minimum entitlement could not depart too markedly from market norms, and anti-discrimination law did not prevent employers from engaging in practices, which while facially neutral adversely affected protected groups. Occupational segregation, for example, replaced outright discrimination as the primary device for maintaining women's subordinate position within the labour market.

In short, the post-war employment law regime was pluralistic in that the three conceptions of justice were institutionalized within it, but it was still liberal voluntarist at its core. Moreover, it was also highly fragmented regionally and sectorally, and the norms of employment were gendered and racialized. 


\section{Stalemate or Beachhead: $1948-1964$}

After the reconversion period, regionalism once again became a defining element of state employment policies as primary jurisdiction over labour relations was transferred back to the provinces. While the federal collective bargaining legislation, the Industrial Relations and Disputes Investigation ACt (IRDI ACt), which came into effect in September 1948, served as a model, its key features were filtered through each province's regional political economy. The most marked variations from the federal model were in Québec and Saskatchewan, which retained the collective bargaining legislation enacted during the war. For organized labour the most disturbing legal development was the willingness of conservative provincial governments to enact legal restrictions on the exercise of trade unions' collective power without imposing equivalent limitations upon employers. ${ }^{48}$

British Columbia saw the greatest amount of such legislative activity. While not as draconian as the anti-communist provisions of the Taft-Hartley Act, for which employers had lobbied, the predominant feature of the postwar amendments to the Industrial Conciliation and Arbitration Act was their anti-union tenor. The labour board was empowered to order a vote on any "bona fide" settlement offer from an employer during a strike or lockout; collective agreements were made actionable at common law; and the board was given the power to cancel the certification of any union striking illegally. These amendments wrapped unions in a straightjacket of legality; any violation of the multitude of restrictions on collective action not only threatened a union's legal status to insist upon recognition, it left it open to costly civil actions. ${ }^{49}$

The beauty of the $\mathrm{BC}$ legislation, from the provincial government's perspective, was that it both shifted the initiation of coercion away from itself and onto the parties, primarily employers, and shifted the locus of the debate about the legitimacy of coercion away from the political arena into the judicial one. It was up to the courts to decide whether the union was liable to the employer for any damages caused by the breach of the collective bargaining statute or collective agreement.

${ }^{48}$ Peter Stuart McInnis, "Harnessing Confrontation: The Growth and Consolidation of Industrial Legality in Canada, 1943-1950," PhD thesis, Queen's University, 1996; Russell, Back to Work?, 228; C.H. Curtis, The Development and Enforcement of the Collective Agreement (Kingston, Ont. 1966), 57-60; H.A. Logan, State Intervention (Toronto 1956); A.W. R. Carrothers, Collective Bargaining Law in Canada (Toronto 1965), 56-5, 61-4; Alvin Finkel, "The Cold War, Alberta Labour, and the Social Credit Regime," Labour/Le Travail, 21 (1988), 123-52, 134-6; A.C. Chrysler, Labour Relations and Precedents in Canada (Toronto 1949), 64.

${ }^{49}$ Stephen Gray, "Woodworkers and Legitimacy: the IWA in Canada, 1937-1957," PhD thesis, Simon Fraser University, 1989, 199, 265-71, 336; Paul Graham Knox, "The Passage of Bill 39: Reform and Repression in British Columbia Labour Policy," MA thesis, University of British Columbia, 1974, 120-33, 158-60; Cartothers, Collective Bargaining Law in Canada, 64. 
This technique of restricting collective action stood in marked contrast to the Ontario approach embodied in the Rights of Labour ACt, which provided a prophylactic for trade unions against attempts by employers to use compulsory collective bargaining legislation to impose civil liability on trade unions by making it clear that a trade union was not a legal entity for the purposes of civil litigation, and that a collective agreement was not legally enforceable in the ordinary courts. Initialty, only Saskatchewan followed this legislative precedent. In most jurisdictions, the questions of a trade union's civil liability and the enforceablity of collective agreements in the ordinary courts remained as controversial and tricky as they were at the beginning of the century. ${ }^{50}$

At the war's end, the courts once again became the pre-eminent forum for dealing with picketing. The reconversion to peace ushered in the heyday of the labour injunction, which was used as a "sword of collective bargaining," rather than a "shield of legal rights." While the BC legislation created a strong impetus for the use of civil actions to tame trade unions, the existing common law and Criminal Code provisions continued to provide effective legal mechanisms for restricting traditional strike related tactics in other jurisdictions. Courts were just as likely in Ontario as they were in BC to find that mass picketing was an illegal form of watching and besetting. ${ }^{51}$

The transition to peace brought the role of the courts to the fore not only in restricting strike-related tactics, but also in determining the scope of powers that labour relations boards could exercise. In Saskatchewan, judges began to read down the labour-friendly legislation and overturn board decisions, prefiguring what would become a see-saw vendetta between the courts versus the legislature and the board over which legal entity had the final say over collective bargaining jurisprudence. $^{52}$

Responsible unions were the only legitimate representatives of workers within the pluralist version of industrial democracy; communist-dominated or sympathetic unions were considered to be beyond the pale. By 1950, with a little assistance from the federal and provincial govemments and some labour boards, both the TLC and CCL union leadership had either purged or side-lined their more radical counterparts. The TLC's expulsion of the Canadian Seamen's Union in 1949, followed by the Canadian Labour Relations Board's 1950 decision to revoke its certification on the ground that as a communist-controlled organization it did not fall within the meaning of a union as defined under the IRDI Act, was simply the most blatant

${ }^{50}$ Carrothers, Collective Bargaining in Canada, 50-1, 57, 59.

${ }^{51}$ Knox, "The Passage of Bill 39," 101-3; Phillips, No Power Greater, 145-6; A.W.R. Carrothers, The Labour Injunction in British Columbia (Toronto 1956), 108-10; 60 Carrothers, Collective Bargaining Law in Canada.

${ }^{52}$ Carrothers, Collective Bargaining Law in Canada, 57-8. 
example of how labour boards and responsible unions colluded to exclude left-wing unions from the benefits of industrial legality. ${ }^{53}$

Despite the fairly rapid increase in trade union membership with the advent of industrial pluralism, the growth of unionization after World War II was extremely uneven. Workers in the resource, mass-production, and transportation industrjes joined their skilled craft brothers in the ranks of organized labour, so that in the mid-1950s "the typical union member was a relatively settled, semi-skilled male worker within a large industrial corporation." Except in Saskatchewan, collective bargaining legislation did not cover public sector employees, thereby excluding increasing numbers of workers from the right to bargain collectively through the union of their choice. Morever, even within the private sector, in which some form of collective bargaining legislation was very likely to apply, certain industries and workplaces were a better fit than others. Only the strongest trade unions obtained anything that approximated industry-wide bargaining and, even then in most cases, it was not legally enforceable. Bargaining unit determination policies adopted and administered by labour relations boards reflected and reinforced fragmentation. Plant-by-plant bargaining became the norm. In the secondary sector, which was highly competitive and labour intensive, the legislation tended to function more as an impediment, than an aid, to union representation and collective bargaining. ${ }^{54}$

- The structural limitations of industrial pluralism were reinforced and overlaid by other features of the post-war compromise. At the macro level, the systemic segmentation of the labour market enabled leading firms to concede higher wages to some organized workers in the core sectors while at the same time a large category of unorganized workers would remain available, helping to lower aggregate labour costs. Workers in core firms shared a narrow economic self-interest in maintaining a segmented labour market, since it provided low-cost consumer goods. Moreover, the composition of the secondary workforce was sufficiently distinct from that of the primary sector such that different working conditions, wages, standards, and the absence of union representation were considered natural, or, at least, uncontroversial. As Ursel observed, "women constituted the largest pool of such labour in Canada and were, therefore, a key component in the segmentation ${ }^{53} \mathrm{E}$. Jean Nisbet, “'Free Enterprise at its Best': The State, National Sea, and the Defeat of the Nova Scotia Fishermen, 1946-47," in Michael Earle, ed., Workers and the State in Twentieth Century Nova Scotia (Fredericton 1989), 171-90; Craig Heron, The Canadian Labour Movement (Toronto 1989), 99-100; Palmer, Working Class Experience, 290-98; Desmond Morton with Terry Copp, Working People (Ottawa 1984), 201-13; William Kaplan, Everything That Floats (Toronto 1987); John Stanton, Life and Death of the Canadian Seamen's Union (Toronto 1978).

${ }^{54}$ Heron, The Canadian Labour Movement, 92; Jane Ursel, Private Lives, Public Policy: 100 Vears of State Intervention in the Family (Toronto 1992), 249-50; Stuart Jamieson, Times of Trouble (Ottawa 1968), 348-9; Eileen Sufrin, The Eaton's Drive; The Campaign to Organize Canada's Largest Department Store (Toronto 1982); Forrest, "Securing the Male Breadwinner," 139-62. 
strategy of capital." So, too, were immigrant workers. During the 1950 s immigration played a central role in the growth of the labour force and as the decade wore on countries outside the British Isles provided an increasingly significant source of labour. A wage and occupational hierarchy, which divided British immigrants from their less affluent eastern and southern European counterparts, was firmly established. ${ }^{s s}$

This racialized occupational and wage hierarchy persisted in the face of legislation that was designed to prohibit discrimination on the basis of invidious distinctions such as race, religion, and ethnicity. Human rights legislation became an important feature of the post-war public policy agenda, although the first piece of anti-discrimination legislation in Canada, Ontario's Racial Discrimination Act, was enacted in 1944. Inspited by the United Nations Declaration of Human Rights in 1948 and drawing upon US models, a series of "fair employment practices" laws were enacted, prohibiting employment discrimination on the grounds of race and religion. In the early 1960 s, discrete fair practices statutes were consolidated into omnibus human rights codes under the authority of permanent human rights commissions, whose function was to administer a discrimination complaints process, to develop public education programs and to advise the govemment on future development of the code. Pioneered in Ontario, by 1965, laws dealing with discrimination in employment on the basis of race, creed, and colour were in force in eight Canadian jurisdictions. ${ }^{56}$

By contrast, most forms of employment discrimination on the basis of sex were permitted by law until the mid-1960s. The only illegal form of sex discrimination in employment was with respect to pay. In 1951; Ontario became the first jurisdiction in the Commonwealth to impose a legal obligation on employers to pay women workers the same wages as men who performed the same work when it enacted the Female Employees Fair Remuneration Act. This legislation was "rooted in the deployment of women's labour during the World War II and in the postwar human rights discourse" and its champions were organized labour, which wanted to ensure that women's low wages would not be used to undercut men's, and women's groups. However, the positive thrust of this legislation was undermined by its narrow commitment to requiring employers to pay women the same as men who performed the same work. Small differences in job descriptions were allowed to

${ }^{55}$ H.C. Pentland, A Study of the Changing Social, Economic and Political Background of the Canadian System of Industrial Relations. Draft Study prepared for the Task Force on Industrial Relations (Ottawa 1968), 170; H.D. Woods, Labour Policy in Canada, 2nd ed., (Toronto 1973), 25; Ursel, Private Lives, Public Policy, 239; Palmer, Working-Class Experience, 306-6; Avery, $A$ Reluctant Host.

${ }^{56}$ R. Brian Howe and David Johnson, "A Study of Provincial Human Rights Funding," Canadian Public Administration, 38, 2 (Summer 1995), 244-45; Walter Tarnapolsky and William Pentney, Discrimination and the Law (Toronto 1985), Chapter 2; Paul Malles, Canadian Labour Standards in Law, Agreement, and Practice (Ottawa 1976), 12-13. 
stand unchallenged as a basis for different wages and a union's consent to occupational segregation was considered to be a legitinate basis for wage discrimination. Employers leamed that it was perfectly legal to avoid paying women the same as men through the practice of occupation segregation. ${ }^{57}$

Formal legal equality for women who sought employment was uneven and contradictory, revealing a "legislative bias towards access rather than equity." On the one hand, there was the extension of basic employment standards, such as minimum wages which were initially designed exclusively for women, to men, legislation providing for women's equal pay was enacted and the legislative barriers to the employment of women, especially married women, were dismantled. On the other hand, different wage rates for men and women workers under minimum wage legislation were the norm across the country until the late 1960 s, unemployment insurance disqualified married women workers, and occupational segregation was legally acceptabie. ${ }^{58}$

Even under propitious economic conditions industrial pluralism had a limited scope. By the mid-1950s, more than 65 per cent of Canadian workers were not union members. In fact, between 1955 and 1965 the percentage of the labour force unionized in Canada dropped from 33.7 per cent to 29.7. Union leaders focused their energies on defending their members' interests, not pursuing a broader agenda of social unionism. The type of reforms that organized labour most often demanded, minimum employment standards, and amendments to workers' compensation, were consistent with a segmentation strategy. In the late 1950 s, provincial governments began to implement a series of changes to minimum standards, with the result that by the mid-1960s there were comprehensive minimum standards across the country. But these standards were significantly lower than those obtained by unionized workers since, by and large, they were devised for the unorganized sector. Employment standards legislation was treated as collective bargaining law's little sister. Thus, labour law, government policies and employer staffing practices, aided in part by union bargaining strategies, converged to help create and sustain a low wage sector, one which, in the long run, would have a drag-down effect on the conditions of all workers. The beauty of the segmentation strategy was that "the state could accommodate the demands of capital for a plentiful supply of cheap labour (wornen and immigrants) and contain the spread of unionization (through a

${ }^{57}$ Shirley Tillotsen, "Human Rights Law as a Prism: Women's Organizations, Unions and Ontario's Female Employees Fair Remuneration Act, 1951," Canadian Historical Review, 72, 1 (1991), 532-57; Robert Malarkey and John Hagan, "The Socio-Legal Impact of Equal Pay Legislation in Ontario, 1946-1972," Osgoode Hall Law Journal, 27, 2 (1989), 295-336. ${ }^{58}$ Ursel, Private Lives, Public Policy, 246-7; Ann Porter, "The Case of Unemployment Insurance," Labour/Le Travail, 36 (1993), 111-44 
cautious implementation of labour relations acts), without unduly provoking organized labour." $\$ 9$

Although the 1950 s and early 1960 s were principally a period of consolidation for industrial pluralism, there were clear signs that a crisis was brewing. Initially, it was expressed on a regional basis. Militancy in Québec, Newfoundland, and British Columbia was crushed by governments and employers who deployed legal techniques ranging from repressive legislation to court actions. ${ }^{60}$

\section{The Golden Age of Industrial Citizenship: 1965-1980}

By the mid-1960s, what had becn regional outbreaks of labour unrest consolidated across the country to form a massive strike wave. In 1966, working days lost to strikes reached an unprecedented number, one-third of which was due to illegal or wild-cat strikes. It appeared that union leaders were either unwilling or unable to keep the contumacious rank and file within the bounds of industrial legality. ${ }^{61}$

Several factors drove workers' militancy. Heavy-handed legislation and judicial decisions that disproportionately restricted workers' collective action, combined with wage increases that lagged behind productivity gains, threatened the legitimacy of the industrial pluralist regime. Automation, especially on the railways and in the post office, not only challenged long-established work rules, but job security. Public sector workers were tired of being treated as civil servants whose freedom of association and right to engage in collective action was subordinated to antiquated notions of political sovereignty. Workers refused to obey the rule of law and struck to achieve their demands.

The strike wave triggered a typicalty Canadian response. The federal government appointed a Task Force, composed of industrial relations experts, to evaluate the existing federal labour relations law and policy. In British Columbia and Ontario, where employers' successful recourse to the courts had begun to tilt the balance away from industrial pluralism and back to individualism and voluntarism, the provincial governments appointed commissions to study the problems caused by labour injunctions. The expert commissions recommended variations on the same solution to the problem of labour unrest - strengthen the institutions of industrial pluralism. The idea was to minimize the vestiges of liberal voluntarism. In British Columbia, jurisdiction to regulate picketing in a labour dispute was transferred from the ordinary courts to labour tribunals, while in Ontario, restric-

${ }^{59}$ Palmer, Working-Class Experience, 299, 301, 305-7; Janine Brodie and Jane Jenson, Crisis, Challenge and Change (Ottawa 1988), 268; Heron, The Canadian Labour Movement, 88; Avery, A Reluctant Host, 198-218; Ursel, Private Lives, Public Policy, 239, 242, 245.

${ }^{60}$ Palmer, Working-Class Experience, 302; Carrothers et al, Collective Bargaining Law in Canada, 64-5.

${ }^{61}$ Gregory Albo, "The 'New Realism' and Canadian Workers," in Alain-G. Gagnon and James P. Bickerton, eds., Canadian Politics (Peterborough, Ont. 1990), 471, 478-9; Palmer, Working-Class Experience, 273, 315-6. 
tions on the granting of injunctions in a labour dispute were tightened. The judiciary was also told to defer to the expertise of specialized tribunals. ${ }^{62}$

The militancy of the 1960 s not only resulted in the strengthening of industrial pluralist institutions, it also led to their extension, albeit in a modified form, to the public sector. Starting in Québec and followed by postal workers across the country, public sector workers, who outside of Saskatchewan did not enjoy any legal right to bargain collectively or to be represented by a union, struck to press for their demands. Governments responded by introducing public sector collective bargaining legislation which, although modelled on private sector collective bargaining statutes, was inferior in several respects, including: restrictions on strikes and lockouts; criteria for arbitration; extensive cooling off measures; restrictions on who could strike; constraints on subjects of bargaining; rules regarding the choice of bargaining agent; and controls on partisan political activity. By 1973, every government in Canada had legislation providing for collective bargaining by public sector workers. The result, however, was a patchwork of measures ranging from the least restrictive model in Saskatchewan and Québec, which extended private sector collective bargaining legislation to the public sector with minimal modifications, to Ontario, which banned collective action outright for government workers. Moreover, with the advent of public sector collective bargaining there was an increase in ad hoc back-to-work legislation. Thus, the regime of industrial pluralism was modified to deal with the distinguishing feature of collective bargaining in the public sector - the absence of market competition as a discipline. Public sector collective bargaining legislation marked the third wave of unionization in Canada and the increased feminization of the labour movement. Between 1966 and 1976, there was a 106 per cent increase in unionization for women compared to a 40 per cent increase for men. ${ }^{63}$

Not only were the institutions of industrial pluralism strengthened and extended, so, too, were the other aspects of the employment law regime. The coverage

${ }^{62}$ Canadian Labour Relations: Report of the Task Force on Labour Relations (Ottawa 1968); A.W.R. Carrothers, The Labour Injunction in British Columbia (Toronto 1956) 108-10;280; A.W.R. Carrothers and E.E. Palmer, Report of a Study on the Labour Injunction in Ontario (Toronto 1966); Royal Commission of Inquiry into Labour Disputes, Ontario (Rand) (Ottawa 1968); H.W. Arthurs, "'The Dullest Bill': Reflections on the Labour Code of British Columbia," U.B.C. Law Review, 9 (1974), 280-340.

${ }^{63}$ Gerard Hebert, "Public Sector Collective Bargaining in Quebec," in Gene Swimmer and Mark Thompson, eds., Public Sector Collective Bargaining: The Beginning of the End or the End of the Beginning (Kingston, Ont. 1995), 210-35; Joseph B. Rose, "The Evolution of Public Sector Unionism," in Swimmer and Thompson, eds., Public Sector Collective Bargaining, 20-52; John L. Fryer, "Provincial Public Sector Labour Relations," in Swimmer and Thompson, eds., Public Sector Collective Bargaining, 341-67; Morely Gunderson and Frank Reid, "Public Sector Strikes in Canada," in Swimmer and Thompson, eds., Public Sector Collective Bargaining, 135 63; Judy Fudge and Harry Glasbeek, "The Legacy of PC 1003," 384-5; Julie White, Women and Unions (Ottawa 1980), 22. 
of human rights codes was expanded beyond groups identified in terms of ineluctable characteristics to include marital status, disability and age, and specialized adjudicative tribunals began to develop a distinctive human rights jurisprudence. Moreover, Canada's international labour commitments and women's increased labour market participation, especially in the expanding public sector, combined with the increasingly vociferous political demands of the second wave of the women's movement to pressure federal and provincial governments to eradicate the last vestiges of protective and sex-discriminatory laws, and to enact legislation designed to remedy the legacy of sex discrimination in employment. Simultaneously, new improved minimum employment standards proliferated and there was a wave of occupational health and safety legislative reform. Writing in 1967, H.W. Arthurs predicted a golden period of industrial citizenship:

Today the Canadian worker lives increasingly in a world of rights and duties creatcd not by his individual contractual act, but by a process of public and private legislation. Mcmbers of the industrial community enjoy these rights and duties solcly by virtuc of their membership in the community. In effect there is emerging a new status - that of "industrial citizen" whose juridical attributes may be analogized to those of citizenship generally. ${ }^{64}$

The next year, the Woods Task Force urged that the distinctive elements of industrial pluralism be strengthened at the expense of the common law notions of freedom of contract and private property. According to it, strikes and lockouts served both as a catalyst and catharsis to parties who had to learn to deal with inevitable distributional disputes while coming to an understanding of their symbiotic relationship. Regulated disruptions served a valuable purpose in legitimating the "superior-subordinate nexus inherent in the employment relationship." Hence, responsible trade unionism had to be encouraged, and wages and conditions of work could bc left to be determined by what were, basically, voluntarily reached agreements. Organizational activities should be given support by granting the distinctive institutions of industrial pluralism, the labour relations boards, more remedial powers and individual contract principles should be negated as much as possible. $^{65}$

Governments across Canada opted for this approach to reducing labour conflict and, unlike the $1950 \mathrm{~s}$, by and large, the amendments to collective bargaining legislation in the 1970s imposed constraints upon employers. A range of labourfriendly changes were made: preambles declaring that public policy supported collective bargaining were added; the remedial powers of boards, especially with respect to unfair labour practices and breaches of the duty to bargain in good faith, ${ }^{64}$ Hucker, "Anti-Discrimination Laws in Canada," 567; Kathlecn Archibald, Sex and The Public Service (Ottawa 1970), 19; H.W. Arthurs, "Developing Industrial Citizenship," 786. ${ }^{65}$ Royal Commission of Inquiry into Labour Disputes, Ontario (Rand) (Ottawa 1968); Ursel, Private Lives Public Policy, 243; Canadian Labour Relations: Report of the Task Force on Labour Relations; Fudge and Glasbeek, "The Legacy of PC 1003," 383. 
were strengthened; provisions for the imposition of first collective agreements in specified circumstances were introduced; unions gained the right to compulsory dues check off; minimum reinstatement rights for workers who participated in economic strikes were enacted; and permanent replacement workers and professional strike breakers were prohibited. In 1977, organized labour achieved the acme of its demands when the Parti-Québécois government introduced legislation that severely limited the right of employers to use temporary replacement workers in a lawful strike or lockout. This step went farther than most industrial pluralist experts were prepared to tolerate. ${ }^{66}$

Just as the institutions of industrial pluralism flourished during the $1970 \mathrm{~s}$, so, too, did direct government intervention. The 1970 s were a period of consolidation of women's participation in the labour market and the women's movement, which had pressured the federal government to establish the Royal Commission on the Status of Women in 1967, actively lobbied for legislation designed to promote sex equality in the workplace and allow women to combine child-bearing with employment. The Commission's 1970 report highlighted the pervasive nature of sex discrimination in the workplace and government legislation. By 1973 employment protection for pregnant employees was provided, in one form or another, in the federal jurisdiction as well as in six provinces, and in 1972 the Unemployment Insurance Act was revised to provide for maternity benefits. As well, human rights tribunals across the country made it illegal for employers to harass sexually female employees. In 1972, the federal government quietly ratified ILo Convention 100 on equal pay for work of equal value. By the end of the 1970s, the federal government, Québec, and the Yukon introduced legislation putting the principle of equal value into practice. Despite both the huge influx of women into the labour market and the legislative commitment to formal equality for women workers in employment in every jurisdiction in Canada, at the end of the 1970s the nature of women's paid work remained quite static. Legal prohibitions against discrimination on the basis of sex, while an important political victory, did not address the range of policies and practices that, while not explicitly discriminatory on the basis of sex, had a discriminatory impact on women workers. Women continued to be crowded into a small range of low-paid occupations. Moreover, the female norm of employment departed significantly from that of men; they were much more likely to work part time and on a temporary basis. ${ }^{67}$

${ }^{66}$ Palmer, Working-Class Experience, 276; Roy J. Adams, “A Pernicious Euphoria: 50 Ycars of Wagnerism in Canada," Canadian Labour \& Employment Law Journal, 3(3/4) (1995), 321-55, 328-29; George W. Adams, Canadian Labour Law, 2nd ed. (Aurora 1994); Jean Boivin and Ester Deom, "Labour Management Relations in Quebcc," in Morely Gunderson and Allen Ponak, eds., Union-Management ReJations in Canada (Don Mills, Ont. 1995), 455-93, 469-71.

${ }^{67}$ Pat Armstrong, Labour Pains: Women's Work in Crisis (Toronto 1984), 53; Ann Porter, "Gender, Class and the State: The Case of Unemployment Insurance in Canada," $\mathrm{PhD}$ thesis, 
By 1970, minimum wages of general application, hours-of-work regulation, public holidays, paid vacations, and notice of termination of employment became the norm in many jurisdictions across Canada. Moreover, during the late 1970s, the model of occupational health and safety regulation that had prevailed since the turn of the century had run out of steam. Worker unrest and renewed concern about the social cost of work-induced disability led to a wave of regulatory reform. These reforms focused on two aspects of the regulatory system, in ways that made it more pluralistic. First, the intemal responsibility system of the firm was reformed by giving workers some legal rights that were exercisable against their employers. The strength of these rights varied from jurisdiction, but they almost always included some kind of right to know about hazardous conditions, a right to participate in discussions about the identification and control of hazards, and a right to refuse unsafe work. The second target was to rationalize and strengthen the external responsibility system by: enacting omnibus health and safety statutes to replace a multiplicity of sector or hazard specific statutes; putting more emphasis on the control of health hazards; and centralizing administration and enforcement in ministries of labour. However, tensions were inmanent within the emerging model. On the one hand, the ideology of common interest provided the foundation for mandated partial self-regulation while, on the other, it was recognized that de facto self-regulation (the result of chronic under-enforcement) had failed in the past. Some countervailing mechanisms were needed to spur employer health and safety activity. In practice, the new oHS regime relied primarily on the reformed internal responsibility system, but in the absence of consensus many workers found themselves powerless to force their employers to act. However, when workers demanded state enforcement, they were often put off by officials on the ground that they should be resolving OHS disputes directly with their employer. In this way, the new regime tried to preserve a core of voluntarism that was consistent with industrial pluralism. $^{68}$

Despite the fact that by the end of the 1970s contract was no longer the dominant principle in collective labour relations, the scope of freedom of association for workers was severely constrained under industrial pluralism. Unions of the responsible kind werc predominantly wholesalers of labour power, not vehicles for

York University, 1998; Gillian Creesc, "Sexual Equality and the Minimum Wage in B.C.," Journalof Canadian Studies, (1991) 26, 120-140, 133; Malles, Canadian Labour Standards, 13; Leah Vosko, "No Jobs, Lots of Work: The Gendered Rise of the Temporary Employment Relationship in Canada, 1867-1997," PhD thesis, York University, 1998; Julie White, Sisters or Solidarity: Women and Unions in Canada (Toronto 1993).

${ }^{68}$ Malles, Canadian Labour Standards, 12-13; Vivienne Walters, "Occupational Health and Safety Legislation in Ontario: An Analysis of its Origins and Content," Canadian Review of Sociology and Anthropology, 20 (1983) 413-34; Eric Tucker, "And Defeat Goes On: An Assessment of the Third Wave of Health and Safety Regulation," in Frank Pearce and Laureen Snider, eds., Corporate Crime: Contemporary Debates (Toronto 1995), 245-67. 
the expression of class power. The separation between the economic and political was firmly policed when it came to workers' collective action. The 1972 common front strikes were met with old-style coercion and union leaders who defied court orders were convicted of contempt, receiving jail sentences of up to a year in duration. While the 1976 CLC-led Day of Protest against the federal Liberal government's Anti-Inflation legislation, which suspended collective bargaining and imposed wage controls for three years, was a much more orderly affair, it, too, received legal sanction. The Supreme Court subsequently affirmed the federal government's right to suspend free collective bargaining across the country on the ground that double-digit inflation constituted a national emergency. Moreover, when Jean-Claude Panot, the leader of the postal clerks, had the temerity to refuse to obey the government's draconian back-to-work legislation, he was charged under the Criminal Code, prosecuted, and convicted. Union leaders who did not control members who defied legal restrictions on their freedom to strike faced incarceration. Collective withdrawal of labour power outside of a tightly restricted economic frame simply was not tolerable. However, the tradeoff was real gains for workers in terms of wages and economic security. ${ }^{69}$

This bargain was of Iimited value for workers employed in the secondary labour market, many of whom were women and members of visible minorities. Industrial pluralism did not provide collective bargaining to one-half of the Canadian workforce. Not only was it perfectly acceptable for employers to oppose unionization, the technical requirements for certification made it simply too risky and too costly for all but the most determined union to attempt to organize the private service sector or small workplaces. The unsuccessful attempt to organize bank workers combined with a series of first contract strikes in the late 1970s and early 1980s (many of which involved women workers), to demonstrate that collective bargaining legislation still operated as a barrier to unionization in certain contexts. Despite this, organized labour's confidence in industrial pluralism was not shaken and it maintained its commitment to incremental law reform. ${ }^{70}$

The legislative refinement of industrial pluralism in the private sector never overcame labour market segmentation. Similarly, the legal emphasis on equal rights, especially those for women, did not penetrate the deeper structural fragmentation embedded in the employment law regime. Moreover, the Anti-Inflation Act of 1975, which imposed wage and price controls across the country, presaged the

${ }^{69}$ Boivin and Deom, "Labour-Management Relations in Quebec," 213; Albo, "The "New Realism' and Canadian Workers," 478-9; Palmer, Working-Class Experience, 344; Danie] Drache and H.J, Glasbeek, The Changing Workplace (Toronto 1991).

${ }^{70}$ Roscmary Warskett, "The Politics of Difference and Inclusiveness within the Canadian Labour Movement," Economic and Industrial Democracy. 17 (1996), 587-625, 595-98, 608; Adams, "A Pernicious Euphoria," 342; Rosemary Warskett, "Bank Worker Unionization and the Law," Studies in Political Economy, 25 (1988), 4 I-73. 
era of coercive controls, or permanent exceptionalism, that undermined industrial pluralism in the public sector almost as soon as it was institutionalized.

\section{Deepening Contradictions: 1980 s}

During the 1970s, the industrial pluralist regime of legality was subjected to contradictory pressures. Initially, the state responded to workers' militancy by strengthening its distinctive features, but, by mid-decade, the federal government's decision to suspend collective bargaining across the country signalled a broader realignment in the post-war entente. The contradiction between equality and monetarist economic policies that was latent in the late 1970s deepened, and by the mid-1980s the postwar employment regime was stretched to its breaking point.

Although the federal Liberal government started off the decade with what amounted to a new national policy, a centrepiece of which was a commitment to individual and equality rights embodied within the Charter of Rights and Freedoms, in the face of the severe recession of 1981-82 it soon targeted its own workers as a scapegoat for the country's cconomic woes. In 1982; it imposed wage controls on them and suspended collective bargaining rights for two years. This legislation, although not as comprehensive as the earlier controls, was significantly harsher. Moreover, the Treasury Board insisted that it had the right unilaterally to designate a government employee as essential and, thus, prohibit them from participating in an otherwise lawful strike. ${ }^{71}$

Most provincial governments quickly followed the federal government's lead, auguring an era of permanent exceptionalism for industrial pluralism in the public sector. By 1983, six provincial governments had imposed variations of the federal government's 6 and 5 legislation on their own workers. There was also a massive increase in the use of back-to-work legislation to end what were otherwise lawful public sector strikes. The decision to target public sector workers for coercive controls transcended the political orientation of the government. Not only did the Social Credit government in BC attack public sector unions, so too did the PartiQuébécois government, which historically had close ties with public sector unions. $^{72}$

The wage control and back-to-work legislation of the early 1980 s presaged a wholesale assault on public sector workers' collective bargaining rights as the decade progressed. The 1984 election of the Conservative Party as the federal government marked an idcological tuming point in Canada as it initiated a round

${ }^{71}$ Palmer, Working-Class Experience, 346; Swimmer and Thompson, eds., Public Sector Collective Bargaining in Canada; L. Panitch and D. Swartz, The Assault on Trade Union Freedoms: From Consent to Coercion (Toronto 1993).

${ }^{72}$ Panitch and Swartz, The Assault on Trade Union Freedoms; Palmer, Working-Class ' Experience, 362; Hebert, "Public Sector Coliective Bargaining in Quebcc," 223; Boivin and Deom, "Labour-Management Relations in Quebec," 374. 
of deregulation and privatization and attacked public spending and the deficit. The legitimacy of the Conservative govemment's economic policies was enhanced by the 1985 Report of the Royal Commission on Economic Union, which had been appointed by the Liberals to assess Canada's economic prospects and suggest how the government should retool the economy to meet the global challenges of the future. The Report strongly advocated the deregulation of the labour market and the dismantling of barriers to trade. According to it, "the presumption must be that in the great majority of cases, the market is the best available mechanism for resource allocation. The burden must be on those who propose intervention." 73

In this political climate, public sector workers' collective bargaining rights had little legitimacy. Not only did the Tories' extend the wage controls on their own workers, they took a no-hold's-barred approach to bargaining, going so far as to authorize, for the very first time by the federal government, the use of replacement workers by a crown corporation. In the spring of 1987, the evening news displayed pitched battles between letter carriers, replacement workers, and police as Canada Post sought to keep the mail moving by using strikebreakers. That fall, the government put an end to the postal clerks' rotating strikes by back-to-work legislation which provided that any union of ficjal who defied it would be deposed from elected office. ${ }^{74}$

The continuing assault on public sector workers' collective bargaining rights was not confined to the federal government. Absolute prohibitions on the right to strike, increases in the proportion of workers designated as essential; limitations in the scope of bargaining, the imposition of ability to pay as a criterion to be considered by arbitrators when fashioning a settlement, and the increase in the power of the executive to end strikes and impose settlements were features common to many of the new provincial public sector collective bargaining regimes. Simultaneously, services were reduced and contracted out, and managers took a harder line at the bargaining table. ${ }^{75}$

Initially, it appeared as if governments would be able to suspend or repeal industrial pluralism in the public sector with impunity. In response to the suspension of collective bargaining and the imposition of wage controls, the Public Service Alliance of Canada lodged a complaint with the $1 L O$, and filed a writ in a Canadian court alleging that its freedom of association had been violated. Unions that used their collective power to protest the infringements on their members' freedoms

${ }^{73}$ Duncan Cameron, "Selling the House to Pay the Mortgage: What is Behind Privatiza* tion?," Srudies in Political Economy, 53 (1997), 11-36, 13.

${ }^{74}$ Palmer, Working-Class Experience, 349-59; Judy Fudge, "The Commercialization of Canada Post: Postal Policy, Business Strategy and Labour Relations," in Anil Verma and Rick Chaykowski, eds., Contract and Commitment: Employment Relations in the New Economy (Kingston, Ont. 1999), 293-337.

${ }^{75}$ Paritch and Swartz, The Assatult on Trade Union Freedoms; Swimmer and Thompson, Public Sector Collective Bargaining. 
were met with legal coercion as governments across Canada invoked the rule of law as a justification for restricting collective action. In the mid-1980s, the Newfoundland Association of Public Employees (NAPE) was subjected to huge fines for engaging in illegal strikes and dozens of picketers werc arrested for violating a court injunction. Ultimately, Fraser March, the president of NAPE, was sentenced to four months in jail and placed on two years probation for contempt of court. In Alberta, the illegailly striking nurses' union ignored the orders of the province's labour board that they renurn to work, only to be confronted with huge fines and court actions for criminal contempt. ${ }^{76}$

While the ILO had little difficulty in finding that governments across Canada repeatedly had violated international covenants designed to protect workers' rights to associate freely and bargain collectively, Canadian courts were not similarly inclined. In the infamous right-to-strike trilogy, the Supreme Court of Canada ruled that the freedom of association guaranteed by the Canadian Charter of Rights and Freedoms did not protect modem legislative rights such as collective bargaining. In fact, each time that unions argued before the Supreme Cout of Canada that legal restrictions on the scope of collective bargaining, the right of workers to select a bargaining agent of their choice, and the right to strike or to engage in peaceful picketing constituted an unjustifiable infringement on fundamental rights and freedoms they were unsuccessful. The highest court made it clear that the Charter protected individual, not collective rights, and that it was not prepared to disturb basic common law principles of contract and private property. Not only did restrictions on public sector collective bargaining rights pass legal muster, so, too, did blanket injunctions and criminal contempt proceedings. However, in 1987 the Vander Zalm government in BC managed to overstep the bounds of acceptable legal coercion when it sought an injunction to stop the onc-day general strike planned by the provincial federation of labour on the grounds the threatened action amounted to the use of force as a means of accomplishing governmental change, and thereby constituted criminal sedition. The BC Supreme Court endorsed the unions' request that the action be dismissed. 7

By contrast with the legislative assault on public sector workers, in the private sector the industrial pluralist regime survived, albeit with increased regional differences. Restrictions on private sector collective bargaining rights depended not only upon the political ideology of the provincial government, but also upon the

${ }^{76}$ Palmer, Working-Class Experience, 359; Panitch and Swartz, The Assault on Trade Union Freedoms, 108, 122-3; Larry Haiven, "Industrial Relations in Health Care: Regulation, Conflict and the Transition to the "Wellness Model," in Swimmer and Thompson, Public Sector Collective Bargaining, 236-71.

${ }^{77}$ Palmer, Working-Class Experience, 359, 393, 404; Panitch and Swartz, The Assault on Trade Union Freedom, 105, 148; Judy Fudge, "Labour, the New Constitution, and Old Style Liberalism," Queen's Law Journal, 13 (1988), 66-111; Harry Glasbeek, "Contempt for Workers," Osgoode Hall Law School, 28 (1990), 1-52. 
nature of the regional economy. In the early 1980s, highly resource dependent economies were severely squeezed, and it was during this period that British Columbia, Alberta, and Saskatchewan introduced changes to their private sector labour relations legislation that made it harder for unions to organize, intervened in their internal affairs, and restricted their ability to resort to collective action. In many respects, these changes were reminiscent of the restrictive provisions enacted by the British Columbia and Alberta governments in the late 1940 s and early 1950 s. $^{78}$

It was only in Manitoba and Ontario that industrial pluralism in the private sector was strengthened. In Manitoba, the NDP govemed for most of the decade and it began its rule in the early $1980 \mathrm{~s}$, before the recession was entrenched, by enacting a series of amendments that labour had been calling for since the 1970s. In Ontario, manufacturing recovered in the mid-1980s, at the same time the Liberals, with the help of the NDP, deposed the long-ruling Tones. The result was some legislative tinkering to the collective bargaining legislation designed to assist unions. ${ }^{79}$

These minor legislative improvements, however, did little to protect workers from the ravages of work restructuring or make it easier for unions to organize the growing secondary labour market. The Gainers strike in Calgary in 1986 epitomized the extent to which a determined employer could call upon the courts for assistance in deploying replacement workers to defeat a strike in the absence of legislative restrictions on the use of temporary replacement workers. Faced with low wage competitors like Gainers, the big three meat packers refused the United Food and Commercial Workers' demand that they maintain industry-wide bargaining, and labour boards across the country ruled that it was unlawful for the union to resort to collective action to insist on anything other than bargaining at the level of the workplace. With the demise of broader-based bargaining in meat packing, wages dropped, unionization declined, and workplace injuries increased. Moreover, provisions such as first contract arbitration did little to shift the balance of power in favour of workers in the private service sector. Contracting out increased and collective bargaining legislation imposed few barriers on employers who were intent on restructuring in ways that had the effect of avoiding unionization. ${ }^{80}$

\footnotetext{
${ }^{78}$ Panitch and Swartz, The Assault on Trade Union Freedoms, Chapters 3 and 5; Palmer, Working-Class Experience, 348.

${ }^{79}$ Panitch and Swartz, The Assault on Trade Union Freedoms. 110,1 19, 128-31; Errol Black and Jim Silver, eds., Hard Bargains: The Manitoba Labour Movement Confronts the 1990s (Wingipeg 1989).

${ }^{80}$ Palmer, Working-Class Experience, 394-5; Alain Noel and Keith Gardner, "The Gainers" Strike: Capitalist Offensive, Militancy and the Politics of Industrial Relations in Canada," Studies in Political Economy, 31 (1990), 31-72; Anne Forest, "The Rise and Fall of National Bargaining in the Canadian Meat-Packing Industry," Relations Industrielles, 44, 2 (1989), 393-407; Carl Cuneo, "Franchising Union Successor Rights," in Cy Gonick et al, eds., Labour Gains, Labour Pains, 307-40.
} 
The recession initiated a fundamental restructuring of the Canadian economy. In 1982, union density peaked at 40 per cent, but it soon began to decline as manufacturing jobs were lost never to return. Unemployment was high and the private service sector outstripped the goods producing sector in creating jobs. The number of annual union certifications dropped from a per year average of $3500 \mathrm{in}$ $1970 \mathrm{~s}$ to 3000 in $1980 \mathrm{~s}$. Workers and their unions were unable to retain real wage levels, strike activity declined, master agreements were torn up, and two tiered contracts were implemented. ${ }^{81}$

At the same time as the collective power of workers was being undermined, substantive equality or equity was being institutionalized in law. The early $1980 \mathrm{~s}$ marked the apogee of second-wave feminism's campaign for women's equality rights; the most prominent being the guarantee of sex equality in the Canadian constitution in 1982. The Liberal government appointed a Royal Commission to examine ways to achieve greater equality for groups historically discriminated against in the labour market. Across the country human rights codes were amended to prohibit indirect discrimination and impose on employers a duty to accommodate individuals who were discriminated against by workplace rules, practices, and policies. Sexual harassment was prohibited and, in several jurisdictions, so too was discrimination on the basis of sexual orientation. As the decade progressed, the highest court adopted a broader, substantive, less formal, approach to sex discrimination overturning outright or limiting a number of decisions from the 1970 s that had restricted women's rights. ${ }^{82}$

In 1985, the equality rights in the Charter of Rights and Freedoms came into effect and Judge Abella issued her report on equality in employment, which coined the term "employment equity." In response, the Conservative government enacted the Employment Equity Act, which covered federally regulated undertakings, and the Federal Contractors Compliance program. This legislation monitored the attempts of federal enterprises to achieve proportional representation for target groups through a public reporting mechanism; it did not impose numerical targets or quotas. By the end of the decade, five provinces had enacted pay equity legislation which imposed a legal duty on employers to ensure that men's and women's jobs of the same value received the same pay, although only the Ontario legislation covered the private sector. ${ }^{83}$

${ }^{81}$ Albo, “'The New Realism' and Canadian Workers," 483, 487-9; Panitch and Swartz, The Assault on Trade Union Freedoms, 14]-4; Palmer, Working-Class Experience, 347.

${ }^{82}$ Sylvia Bashevkin, Women on the Defensive: Living Through Conservative Times (Toronto 1998); W.A. Bogart, Courts and Country: The Limits of Litigation and the Social and Political Life of Canada (Toronto 1994), 147, 249; Shelagh Day and Gwen Brodsky, Women and the Equality Deficit: The Impact of Restructuring Canada's Social Programs (Ottawa 1998), 54-67.

${ }^{83}$ Rosemary Warskeft, "The Politics of Diffcrence," 613; Mary Cornish, "Employment and Pay Equity in Canada-Success Brings Both Attacks and New Initiatives," Canada - U.S. Law Journal, 22 (1996), 265-77; Panitch and Swartz, The Assault on Trade Union Freedoms, 
But the problem was that neither pay nor employment equity legislation did anything to stop the underlying deterioration in terms and conditions of employment generally. The emphasis on substantive equality at a time when the labour market was polarizing and employment conditions for the majority of workers were deteriorating fuelled a backlash against equality which gained momentum in the $1990 \mathrm{~s}^{84}$

On the employment standards front, there was a flurry of legislative activity to improve maternity leave entitlements and provide parental leave. Québec went the farthest in requiring employers to accommodate the family and employment responsibilities of their workers. Ontario led the pack when it came to notice and severance pay. It also made extensive revisions to its Occupational Health and Safety $A c t$ in response to a number of plant occupations designed to force the state to ensure that employers met their legal obligations to provide a safe workplace. The main thrust of the amendments was to extend the bipartite structures for monitoring and regulating workplace health and safety down to the shop floor. This had the effect of absolving the government of responsibility in the setting and enforcing of health and safety standards and shifting it to the labour market parties. In the economic context of the 1980 s, the effect of the legislation was to make occupational health and safety regulation even more market driven. ${ }^{85}$

- The massive lay-offs of non-unionized, middle-level employees in the early 1980 s resulted in an explosion of wrongful dismissal litigation. Employees argued that dismissal for economic reasons did not constitute just cause at law and that employers were required to pay them damages that amounted to reasonable notice. Courts accepted this argument; however, since reasonable notice was linked to the length of employment service, the employee's age and occupational status, wrongful dismissal litigation, and severance packages tended only to benefit a narrow band of employees relatively high up in the occupational hierarchy. The increasing numbers of contingent workers employed in part-time, temporary, and low status jobs derived little benefit from the common law. ${ }^{86}$

By the time the Conservative government won its second consecutive federal election in 1988, privatization had eclipsed equality as the dominant discourse in

132-6; Weiner, "Workplace Equity," in Swimmer and Thompson, cds., Public Sector Collective Bargaining, 78-102, 93-4.

${ }^{84}$ Judy Fudge, "Fragmentation and Feminization: The Challenge of Equity for Labour Relations Policy," in Jane Brodic, ed., Women and Canadian Public Policy (Toronto 1996), 57.87; Warsket, "The Politics of Difference," 617.

${ }^{85}$ Boivin and Deom, "Labour-Management Relations in Quebec," 482; Judy Fudge, Labour Law's Litle Sister: The Employment Siandards Act and the Feminization of Labour (Ottawa 1991); Panitch and Swart, The Assault on Trade Union Freedoms, 129-30; Tucker, "And Defeat Goes On."

${ }^{86}$ Geoffrey England, Innis Christie, Merrit Christie, Employment Law in Canada, 3rd ed. (Toronto 1998). 
Canadian politics. The Free Trade deal with the United States was the most profound step in the direction of economic continentalism and symbolized the hegemony of neo-liberalism. The emphasis on market-driven restructuring and the renewed legitimacy of individual ordering through contract and private property undermined the conditions upon which the industrial pluralist regime in the private sector had flourished without requiring a frontal assautt on its central tenets. During the 1980 s it was possible for governments simultaneously to exalt the superiority of market voluntarism, on the one hand, and substantive equality, on the other, when it came to the legal regulation of the labour market. The decade not only demonstrated the significance of broader macro-economic forces and political shifts on the law, it also demonstrated the flexibility in the regime of liberal legality. At the same time as courts and legislatures institutionalized the concept of substantive equality within the law, governments did not face any legal constraints in introducing labour market policies that heightened fragmentation and increased inequality.

\section{The Hegemony of the Market: The 1990s}

During the 1990s, the federal government abandoned the last shreds of any commitment to full employment in its determination to fight the deficit and, together with provincial governments, substituted workfare for welfare as the guiding theme of social policy and embraced flexibility as the defining characteristic of a well functioning labour market. New technology and increased international trade were the drivers behind the economic revolution known as globalization, and nation states argued that it was necessary to submit any vestiges of political control over their national economies to the logic of the international matket. In Canada, this economic wisdom was firmly institutionalized and it transcended traditional party politics; the 1988 Free Trade Agreement with the United States, negotiated by the Tory government, was extended to include Mexico by the Liberals in 1993. The need to adjust to international competition was used to justify the deteriorating standard of employment and the degradation of the social wage. Polarization and inequality in the Canadian labour market increased. Economic restructuring undermined the conditions for industrial pluralism to function in the private sector and simultaneously fuelled resentment against public sector workers and legal measures designed to achieve equality in employment. As legislatures across Canada asserted the primacy of market voluntarism and individual liberty, the courts increasingly became the defenders of equality; however, they were less willing to protect workers' rights to engage in collective action. Moreover, the very nature of the employment relationship was being transformed as capital has sought to shift the risks of production even further on to workers by avoiding 
all forms of political and legal regulation other than the individual liberty of the commercial contract. ${ }^{87}$

During the 1991-92 recession, the attack on the public sector deepened and the commitment to industrial pluralism was permanently undermined in favour of unilateral paternalism. No longer was the assault on the collective bargaining rights of public sector workers characterized as a temporary inflation fighting measure, but, rather, governments across Canada announced that they wanted to lead the way in wage restraint. Public sector unions were confronted with a choice between two evils: either accept wage freezes and reductions or endure massive lay-offs. In general, governments invoked three general types of measures: the first, legislated wage controls; the second, hard bargaining; and the third, unique to $B C$, the implementation of co-operative processes, reinforced by inducements, to engage public sector unions in cost reduction exercises. The first two measures provoked a wave of militancy as public sector workers across the country struck, following the precedent set in the 1980s by Québec and Newfoundland public sector workers and nurses. ${ }^{88}$

Once again, the federal government led the attack against public sector workers. In 1991, it announced that wage increases for its employees would be capped at 3 per cent and threatened to legislate the right to contract out public service work. In response, PSAC embarked on the largest strike by a single union in Canada's history as over 100,000 workers walked off the job. Although the government was found to have bargained in bad faith, it nonetheless legislated its employees back-to-work on terms virtually identical to what it had initially offered. Once elected, the Liberals simply extended the former Conservative government's wage controls until 1997. In its complaint to the ILO that the federal government was violating its members' right to bargain collectively, PSAC documented how the 1994 controls were but the latest installment in the campaign, first begun in 1981 by the Liberals, to retrench upon public sector workers' rights. The Freedom of Association Committee of the ILO expressed "its serious concern at the frequent recourse had by the [Canadian] Government to statutory limitations on collective bargaining. ${ }^{89}$

${ }^{87} \mathrm{Jim}$ Stanford, "Discipline, Insecurity and Productivity: The Economics Between Labour Market "Flexibility," in Jane Pulkingham and G. Ternowetsky, eds., Remaking Canadian Social Policy (Halifax 1996), 130-150; Greg Albo, "'Competitive Austerity' and the Impassc of Capitalist Employment Policy," in R. Miliband and L. Panitch, eds., Socialist Register 1994: Beyond Globalism and Nationalism (London 1994), 144-70.

${ }^{88}$ Fryer, "Provincial Public Service Labour Relations," 351.

${ }^{89}$ Gene Swimmer, "Collective Bargaining in the Federal Public Service of Canada: The Last Twenty Years," in Swimmer and Thompson, eds., Public Sector Collective Bargaining, 368-407; International Labour Orfice, 297th Report of the Committee on Freedom of Association," 282nd Session, Geneva, March-April, 1995, Case No. 1758, 53-65; Leo Panitch and Donald Swartz, "What happened to freedom of association?," The Globe and Mail, 7 April 1998. 
While the federai government's attack on its workers may have been the most blatant, that by the NDP government in Ontario was the most duplicitous. It illustrated the extent to which economics trumped ideology; shortly after the social democratic party was elected, Ontario experienced the deepest recession since the Depressions. In 1993, the Rae government announced its Expenditure Control Plan, which would entail the loss of 11,000 jobs as part the $\$ 4$ billion cut in expenditures, and its Social Contract, by which it hoped to induce public sector unions to participate in neo-corporatist arrangements in order to lend an aura of legitimacy to the imposition of a three year wage freeze on over 900,000 workers in the broader public sector. Although the government called its initiative a social contract, it used the threat of an additional 20,000 to 40,000 job cuts as a stick to prod labour. When the union-led Public Services Coalition rejccted the government's terms and unveiled an alternative plan, the government went ahead and legislated The Social Contract Act, making a mockery out of the notion of a voluntary agreement. It imposed a three year wage freeze and empowered employers both to open unilaterally collective agreements in order to achieve the mandated cuts, allowing thern to impose up to 12 days of unpaid leave, and to ignore provisions in the Employment Standards Act. As a gesture to equity, workers earning under $\$ 30,000$ a year were exempted from the roll backs and the government guaranteed that the controls would not affect pay equity. As a sop to voluntarism, it gave unions and employers just over a month to reach agreements on compensation reductions, with the inducement that "voluntary" agreements would only have to meet 80 per cent of the imposed cut-back, and laid-off workers would be able to access a Job Security Fund. To add insult to injury, the same day that it imposed the Social Contract, the NDP government also amended the Crown Employees Collective Bargaining Act, which perfected industrial pluralism for government workers by extending the right to strike to them. Public sector unions' response was to withdraw their support from the NDP, which was soundly trounced by the Tories in the 1995 election, and file a formal complaint with the ILO. ${ }^{90}$

Public sector workers only enjoyed the institutions of industrial pluralism for a decade before they were suspended by the Anti-Inflation Act in 1975. Beginning in the 1980 s, their collective rights were subject to legislative assault, with the result that their wages have declined both in real terms and relative to the private sector. Moreover, thousands of jobs were lost due to downsizing, privatization, and contracting out. The extraordinarily coercive measures deployed against public sector workers were justified on the ground that the market does not have control

\footnotetext{
${ }^{90}$ Fryer, "Provincial Public Service Labour Relations," 357-9; Panitch and Swartz, The Assault on Trade Union Freedoms, 169-175; Stephen McBride, "Coercion and Consent: the Recurring Corporatist Temptation," in Gonick et. al., eds., Labour Gains, Labour Pains, $70-96,88-90$.
} 
over the public sector. In the absence of competition, repression is necessary to discipline public sector workers. The Ontario Conservative government took this logic to an extreme when it revoked union successor rights, thereby ousting unions and abrogating collective agreements, when a public enterprise is sold to private interests.

In the 1990s, changes to collective bargaining legislation in the private sector were increasingly ideologically driven. Although the basic structure of the post-war legal regime remained intact, provincial governments, depending upon their political persuasion, tinkered with it either to make it easier for unions to organize and obtain collective agreements or imposed additional requirements on union certification in the name of protecting individual freedom in the face of "big" labour. In the early 1990s, NDP govermments, first in Ontario and then in BC, introduced a series of amendments to private sector collective bargaining legislation that gave unions much of what they had been asking for since the 1970s. The most significant changes included easier access to certification and first contract arbitration, expedited unfair labour practice procedures, and restrictions on the use of replacement workers. By contrast, Conservative governments in Alberta, Manitoba, and later, Ontario, introduced legislative reforms that revoked the traditional Canadian practice of certifying trade unions on the basis of membership evidence, and implemented the US model of requiring a representation vote in every instance. The breakdown of the post-war consensus on the benefits of union representation and collective bargaining was most sharply illustrated in Ontario, where the Conservative government repealed the previous NDP government's amendments without holding public hearings, calling its new legislation An Act to Restore Fairness in Collective Bargainitg. ${ }^{92}$

Despite some modest attempts to update collective bargaining legislation to bring it in line with the labour market of the $1990 \mathrm{~s}$, the regime lost much of its purchase. Social democratic initiatives to refine industrial pluralism were too little, too late; the changes simply did not meet the challenges posed by the restructured labour market. Economic restructuring and corporate reorganization, especially vertical disintegration achieved via out-sourcing and contracting out, and the proliferation in the use of non-standard employment undermined the effectiveness of industrial pluralism in the private sector.

Union density in the private sector decreased across Canada, in part due to the changing composition of economic activity. From 1976 to 1992 union density in the goods sector declined from 43 to 38 per cent. This substantial decline is largely accounted for by the drop in employment and the consequent decline of unioniza-

91 John Price, "Post-PC 1003: A Return to Coercion or New Directions for Labour?" in Gonick et al, eds., Labour Gains, Labour Pains, 253-83, 266.

${ }^{92}$ Panitch and Swartz, The Assault on Trade Union Freedoms, 165-9,175-9; Russell, "Labour's Magna Carta?," 176; Boivin and Deom, "Labour-Management Relations in Quebec," 461. 
tion in manufacturing: the share of paid workers in manufacturing dropped from 22 to 16 per cent and their unionization rate dropped from 43 to 33 per cent from 1976 to 1992 . In contrast, the service sector saw major growth both in employment and unionization during the same period; however, the growth in unionization was largely confined to the public service sector, which was under attack. ${ }^{93}$

Not only was organized labour unable to unionize the private service sector, increasingly it was unable to defend what it had won. The informal bargaining structures, master agreements, and pattern-bargaining in particular, that large industrial unions developed to mediate and modify the fragmentation that resulted from the formal bargaining structure, were rejected by employers on the grounds that they faced increased competition and industrial restructuring. Beginning with meat-packing, employers in the steel, forest, and pulp and paper industries opted out of broader bargaining structures. Since unions do not have the legal right to use economic sanctions to compel employers to recognize a modified bargaining structure there was little they could do to halt the decentralization and fragmentation of bargaining. ${ }^{94}$

There has also been a downward trend in wage settlements and an upward trend in long-term collective agreements. In 1994, Québec amended its collective bargaining legislation to permit collective agreements of six years duration. Moreover, in the resource sector once powerful unions have agreed to accept wage reductions in the event that world prices for commodities fall. Throughout the $1990 \mathrm{~s}$, capital has been very successful in shifting more of the risks of production on to workers without sharing the profits. ${ }^{95}$

The contraction in unionization in the private sector has gone hand in hand with an crosion of standard employment - full time, indeterminate employment with one employer. The proliferation of non-standard employment arrangements has been the most significant recent labour market trend. In 1997, the growth of nonstandard employment was so extensive in the 1980 s and 1990 s that only 33 per cent of Canadian workers were said to hold "normal jobs." Moreover, its increase coincides with growing polarization in eamings amongst Canadians, which has deepened labour market poverty, especially among the young and the old. Young male workers - especially those that already had low earnings - bore the brunt

${ }^{93}$ Emest B. Akyeampong, "A Statistical Portrait of the Trade Union Movement," Perspectives in Labour and Income (Winter 1997) 45-54.

${ }^{94}$ Fudge and Glasbeek, "The Legacy of PC 1003," 394; Ann C. Frost and Anil Verma, "Restructuring in Canadian Stecl: The Case of Steelco Inc.," in Verma and Chaykowski, eds., Contract and Commitment, 82-112.

${ }^{95}$ Panitch and Swartz, The Assault on Trade Union Freedoms, 143; Peter Kennedy, "Miners" Union cndorses Highland's wage offer," The Globe and Mail, 26 August 1999; Mark Mackinnon, "Inco lockout boosts world nickel price," The Globe and Mail, 17 Sept. 1999; Boivin and Dcom, "Labour-Management Relations in Qucbec," 461. 
of this trend, as evidenced by the widening gap between the highest and the lowest eaming men. ${ }^{96}$

The heightened polarization in men's wages has accompanied a convergence in men's and women's wages and employment profiles, and an increased wage and employment polarization among women workers. While fragmentation is still gendered, it is less so than it was prior to the mid-1980s and increasingly it has taken a generational form in light of the restructured labour market. The deterioration in the standard employment relationship, especially for young men, has fuelled a backlash against equity initiatives directed at women and members of visible minority groups. This was most evident in Ontario, where a centre-piece of the Conservative Party's campaign against the NDP government was its attack on the Employment Equity Act of 1993. The Tories' charge that the NDP legislation was a form of illegitimate reverse discrimination had a great deal of popular appeal. One of its first legislative moves was to enact the Act to Repeal Job Quotas and Restore Merit. $^{97}$

Pay equity legislation, even in Ontario under the Tories, survived the backlash. However, it is not clear that governments will fund equal pay. Unless they do, employers in the broader public sector will be faced with the choice of laying off workers to make good on pay equity obligations. In the Atlantic provinces, pay equity has been sacrificed to public sector wage restraint. In 1999, the federal government reluctantly decided to ante up $\$ 3.8$ billion owed to members of PSAC when the federal court upheld the Canadian Human Rights Tribunal's nuling. However, the PSAC decision became the focus of an equity backlash. It was portrayed in the press as unfair to taxpayers and a deviation from market norms. ${ }^{98}$

The response to employment equity also illustrates this process. Although the federal government strengthened its Employment Equity Act in 1995, the statute does not impose an obligation on the government to create new positions in order to achieve proportional representation in the occupational hierarchy. What it does is impose an obligation on employers to report on the composition of their workforce and make all reasonable efforts to eradicate systemic barriers to propor-

${ }^{96} \mathrm{~B}$. Lipsett and M. Reesor, Flexible Work Arrangements: Evidence from the 1991 and 1995 Survey of Work Arrangements (Ottawa 1997); Michael Baker and Gary Solon, "Earning Dynamics and Inequality Among Canadian Men, 1976-1992: Evidence from Longitudinal Tax Records," Statistics Canada, Research Papers Series, 130, Analytic Studies Branch (Ottawa 1999); G. Picot, "What is Happening to Eamings lnequality and Wages in the 1990s?" Statistics Canada, Cat. I1F0019MPGE No. 116 (Ottawa 1998).

${ }^{97}$ Katherine Scott and Clarence Lochhcad, "Are Women Catching up in the Eamings Race?," Canadian Council for Social Development, Paper No. 3 (1997), 2; Mark MacKinnon, "Women gaining ground in the workforce," Globe and Mail, 19 April 1999; Comish, "Employment and Pay Equity," 273.

${ }^{98}$ Patricia Hughes, "A Model for Future Challenges to Government Action," Canadian Labour and Employment Law Journal, 6 (1998), 77-97; Fudge, "Exclusion, Discrimination, Equality and Privatization." 
tional representation for equity groups. Despite the weakness of the equity provisions, the legislation is increasingly regarded as unfair. The attack against substantive equality initiatives such as those embodied in pay and employment equity legislation is fuelled both by a defence and celebration of the free market, on the one hand, and declining economic prospects for young men, on the other. These two elements are united by a shared commitment to an equal opportunities framework, one that sees the role of the state as limited to prohibiting overt discrimination and a return to formal conceptions of legal equality. ${ }^{99}$

During the 1990s, with a few social democratic exceptions, legislatures across Canada lost what little taste they had for measures designed to achieve substantive equality in employment. In this context, courts were regarded as the last bastion for preserving any public policy commitment to equity. The Supreme Court of Canada has issued a number of decisions that have strengthened employers' obligations to provide a discrimination-free workplace and to make accommodations for individuals who are adversely affected by workplace rules, policies, or practices. Moreover, the Court has also imposed corresponding duties on unions not to discriminate and to make workplace accommodations. It has also issued a number of decisions that have tempered the obvious harshness of the common law of employment and reinforced a remedial approach to the interpretation of employment standards legislation. However, although the Supreme Court of Canada has acknowledged the inequality in bargaining power in the labour market, it has refused to take any significant initiatives to ameliorate it on the ground that it is the appropriate responsibility of elected officials. Occasionally, this hands-off approach has redounded to the advantage of organized labour; in Lavigne the Court upheld the use of the compelled dues check off for political purposes. Moreover, in 1999, the Court made a slight detour from its position of deference to legislatures in the realm of collective bargaining when it held that legislative restrictions on peaceful consumer leafleting for informational purposes by unions amounted to an unjustifiable violation of the Charter's guarantee of freedom of expression. However, in permitting the practice of consumer leafletting in the labour context, the Court was careful to distinguish this informational activity from the coercive activity of a conventional labour picket. ${ }^{100}$

\footnotetext{
${ }^{99}$ Comish, "Employment and Pay Equity," 271; Fudge, "Exclusion, Discrimination, Equality and Privatization."

${ }^{100}$ Both British Columbia and Québec introduced pay equity, although only Québec's took the form of legislation and extended to the private sector. Katherine Swinton, "Accommodating Equality in the Unionized Workplace," Osgoode Hall Law Journal 33, 4 (1996), 703-47; BC (Public Service Employee Relations Commission) v. BCGSEU, [1999] 3 S.C.R. 3; Judy Fudge, "New Wine into Old Bottles?: Updating Legal Forms to Reflect Changing Employment Norms," U.B.C. Law Review, 33, I (1999),183-209; Panitch and Swartz, The Assault on Trade Unions Freedom, 185; U.F.C.W., Local I518 v. KMart Canada Ltd., [1999] 2 S.C.R. 1083.
} 
Like collective bargaining legislation, the fortune of employment standards statutes has depended upon the political persuasion of the government in power. Generally, however, improving minimum employment standards or revising them to meet the changed labour market has been portrayed as pricing Canadian workers out of jobs. More troubling is the fact that many standards are simply not enforced as governments across Canada have gutted the bureaucracies which had the authority to enforce the legislation.

Workers' compensation has also been reshaped by neo-liberalism. Under the guise that workers' compensation boards are running huge unfunded liabilities, caused by overly generous benefits, several provinces have changed their workers' compensation legislation. Some of the measures directly attack injured workers by reducing benefit levels, denying compensation for certain types of injuries, such as those caused by workplace stress, and limiting compensation for chronic pain. Other measures are more subtle, but equally harmful. For example, in some jurisdictions fixed pensions for permanent disability have been replaced by wageloss systems that allow boards to reduce or eliminate payments to injured workers on the ground that there is theoretically a job in the labour market they are capable of performing, even though they are unemployed. Similarly, return to work obligations are often evaded or provide a pretext for hiding lost-time injuries. Finally, the increased reliance on experience rating in funding workers' compensation systems detrimentally effects injury reporting and more closely aligns occupational health and safety with market measures of value. ${ }^{101}$

\section{Conclusion}

At the end of the millemium, individualism, competition, and the legal relations of contract and property vie with the official discourses of industrial pluralism and industrial citizenship for hegemony in the labour market. Ideologically, workers' collective action is increasingly portrayed as the self-serving and coercive privilege of big labour and, materially, it has less purchase in a world in which capital is less fettered by the political strictures of the nation state. While there has been no direct and sustained legal assault on private sector workers' freedom to associate and right to bargain collectively, the terrain on which these rights operate has narrowed. As an ever greater proportion of the labour force falls outside the scope of the institutions of industrial pluralism, political support for workers' collective rights is undermined, and the balance is likely to shift even farther towards individualism. Simultaneously, the legislative assault on public sector workers' collective rights illustrates the extent to which industrial pluralism is based upon a fundamental commitment to market voluntarism. It also evinces the degree to which fragmentation and competition between workers has been intemalized; governments across ${ }^{101}$ Geoffrey C. Beckwith, "The Myth of Injury Incentives in Workers' Compensation Insurance," New Solutions (Winter 1992), 52-73; T.G. Ison, "The Significance of Experience Rating," Osgoode Hall Law Journal, 24 (1986), 723-42. 
Canada have faced little opposition in dismantling industrial pluralism in the public sector.

The project of globalization and the accompanying logic of the race to the bottom have also made suspect legally enforceable minimum standards that constrain the exploitation of labour. Conservative and social democratic governments wam Canadian workers that legal standards which provide a living wage, a modicum of dignity at work and personal time outside of employment will price them out of the global labour market. At the same time, deep cutbacks to the public sector have undermined the capacity of the state to enforce employment legislation and the benefits of voluntary, co-operative bipartite arrangements are invoked to legitimate the devolution of standard setting and enforcement to the market parties. In the current economic context, this shift in responsibility favours capital at the expense of workers.

Unbridled capitalism has no respect for human rights. ${ }^{102}$ While it is extremely difficult in a liberal democracy to revoke guarantees of formal legal equality after they have been won, such measures do not address the deeper, structural relations and institutions that generate and sustain substantive inequality. The partial legal institutionalization of substantive equality in Canadian law, itself the product of struggle, is under attack as people face tougher economic times. The "excessive" demands of feminists and "urifair" competition from poorly skilled immigrant labour are being blamed for the declining economic prospects of young white men. The unequal division of household labour; especially with respect to the care of children, will likely only deepen women's historical disadvantage in an increasingly competitive labour market. Human rights legislation which addresses discrimination on the basis of ineluctable characteristics, does not deal with inequality that is increasingly expressed on a generational, occupational, and educational basis.

Moreover, employment is no longer secure as the favoured means of organizing productive activity in a capitalist economy; unfree forms of labour - prison, indenture, and slave - and sweatshop conditions have increased internationally. In liberal societies, there has been a growth in the use of forms of labour that fall outside the traditional contract of employment, which, for all its inequality, was premised on a notion of mutuality. Nonstandard forms of employment, which includes a proliferation in independent contracting, may enhance individual freedom, but they also expose workers to greater risks. ${ }^{103}$

The official discourses and institutions of industrial pluralist legality and industrial citizenship may be losing. their hegemonic status, but in Canada and Québec we have not yet reached a crisis of legitimacy. If such a crisis comes, it may initiate a more radical break than the transitions between the regimes examined here. These regimes werc born of workers' engagement with the liberal democratic

${ }^{102}$ Jacoby, Laboring for Freedom, 149.

${ }^{103}$ Fudge, "New Wine into Old Bottles," 197-9. 
state, which, despite its limitations, still preserved the idea that citizenship mattered and that the boundary between the political and the economic was permeable. The Jiberal state could be made to respond to social demands democratically expressed. It could impose limits on private property and freedom of contract.

The continuing political saliency of the liberal state can no longer be assumed. Democratic citizenship is being systematically narrowed by supra-national free trade regimes that require nation states to recognize the rights of property owners over the claims of their citizens. Such charters of corporate rights and international trade dispute resolution mechanisms have not been matched either by the guarantee of social rights or the creation of credible alternate institutions through which democratic demands can be effectively pursued. Instead of being a site for the mediation of class conflict, the liberal state is increasingly becoming a vehicle for imposing the discipline of the competitive market on its populations. ${ }^{104}$ Much of this has been accomplished by convincing people that they have no choice since the forces of globalization are irresistible.

Increasingly, this ideological project is being contested. In the late 1990s, for example, the Days of Action campaign protested the Conservative government's attempt to institutionalize its slogan "Ontario: Open for Business." 105 Public and private sector unions, together with social movements representing women, visible minorities, disabled people, and the poor, marched in nine cities across the province, closing businesses and disnipting normal activities. In Toronto, there was an unprecedented display of solidarity as close to a million people took to the streets. However, the campaign foundered not so much because it pushed the limits of legality, but more because it ran aground on existing forms of fragmentation. Although workers' participation in the Days of Action was met by employers who sought injunctions and labour board orders to ban unlawful economic action, adjudicative officials refused to do the dirty business of repressing workers. In a liberal democracy, when public opinion supports workers' collective action the constraints of the law are loosened. The more difficult problem has been to forge solidarity in the face of historical lines of fragmentation. Private sector unions, in general, consider that their members provide the labour power fuelling the engine of economic activity and have a correspondingly low respect for public sector workers, although in certain sectors this is changing. Thus, it is difficult to persuade them to make sacrifices for workers who they consider to be a tax burden. Moreover, despite declining membership, unions still have a much stronger finan-

\footnotetext{
${ }^{104}$ Linda Weiss, "Globalization and the Myth of the Powerless State," New Lef Review, 225(1997), 3-27; Joachim Hirsch, "Globalization of Capital, Nation-States and Democracy," Studies in Political Economy, 54 (1997), 39-58; Gary Teeple, Globalization and the Decline of Social Reform (Toronto 1995).

i0s Bryan Palmer, "Halloween in Harrisland," Canadian Dimension, 32, 1(January/February 1998), 29-32; Marcella Munro, "Comment on Ontario"s Days of Action and Strategic Choices for the Left in Canada," Studies in Political Economy, 53 (1997), 125-40.
} 
cial base and more firmly established institutional supports than do social movements, which tend to represent those people in the labour market who have only enjoyed a second-class industrial citizenship. With social movements considered by organized labour to be little more than a junior partner, there is little pressure on unions to expand beyond narrow economism to a full-fledged support for social unionism. So far, despite repeated examples of its limits, especially in the context of a global competition for capital, the labour movements in Canada and Québec remain committed to a political program that consists of supporting the social democratic party, rather than providing an altemative vision of how society should be organized.

Economic restructuring and increased competition have exposed the limits of industrial pluralism. Although it is one of the highest mediations of the conflict between capital and labour, no legal regime can resolve the enduring problem of liberalism, the fundamental contradiction between labour as a commodity and the social solidarity necessary for the reproduction and sustenance of human life. All the regimes of industrial legality arise out of capitalist formations and the conflicts endemic to them. No regime has overcome or resolved finally the conflict that arises out of the commodification of labour power, although a central project of all of them has been to legitimate that commodification ideologically and materially, and to encourage existing organizations of workers to behave responsibly as wholesalers of the labour power of their members. Liberal voluntarism accommodated craft workers in this way at the beginning of the 20 th century, just as industrial pluralism accommodated industrial workers in core sectors fifty years later.

But the material benefits that underwrite the ideological appeal of norms of voluntarism are only available to some workers for some of the time. Fragmentation and segmentation are inherent in the labour market, which, after all, is based upon competition between workers. "Given the fear induced by the basic insecurity of the labour market, workers tend to erect barriers against 'outsiders' in order to protect their 'privileged' position in relation to wages and the state."106 Women workers and immigrants are regarded as a source of competition that puts downward pressure on men's wages, and a decent social wage and strong public sector are seen as diminishing the purchasing power of wages. Too often these views have been accepted as common sense within the labour movement. The political effect of such Malthusian notions is to displace social conflict from the profit/wage relation to an internal struggle within the working class.

There are indications, however, that some elements within organized labour have understood the limitations of strategies based upon the goal of narrow protectionism rather than that of social transformation. Campaigns that disclose the link between the imperatives of unbridled consumerism and sweated labour, especially in the international apparel and footwear industries, are gaining ground.

${ }^{106}$ Antonella Picchio, The Social Reproduction of the Labour Market (Cambridge 1992), 138. 
Some public sector unions have been able to teach their counterparts in the private sector the significance of socially necessary labour. In some industries, such as auto, workers are located in a segment of the labour market that enables them to tackle historical forms of fragmentation around the sexual division of labour and across generations through collective bargaining. ${ }^{107}$ The political challenge is to demonstrate how rapacious capitalism really is and to link the exploitation of working people with other forms of invidious discrimination. The distinction between the traditional working class, as represented by the labour movement, and social movements, comprising among others women, racialized groups, and social welfare recipients, must be abandoned because it reflects and reinforces, rather than challenges and minimizes, the social distinctions and political power that are part and parcel of labour market segmentation.

A concerted attempt by working people, broadly understood, to challenge market voluntarism would likely be met by old-style coercion. An assault on trade union rights may be the trajectory for the reconstruction of a new regime of industrial legality in the neo-liberal, global competitiveness state. ${ }^{108}$ But such a regime would undermine what little basis that continues to exist for social cohesion and social stability. Historically, working people have not passively acceded to institutional and legal arrangements that fail to incorporate at least some of their demands. For legitimacy's sake, the nation state has leavened coercion with accommodation in responding to workers' collective action. It is unlikely that in the new millennium, despite the shift in power in its favour, capital can achieve on a global scale what it has been unable to achieve nationally.

\footnotetext{
${ }^{107} \mathrm{Kim}$ Moody, Workers in a Lean World: Unions in the International Economy (London 1997).

${ }^{108}$ For some interesting reflections on these questions by a one-time active supporter of and participant in the industrial pluralist regime, see H.W. Arthurs, "Labour Law Without the Stale?," University of Toronto Law Journal, 46 (1996), 1-45.
} 